\title{
Implementation of the Junior High School Mathematics Curriculum
}

\author{
Maria Teresa T. Garcia and Ma. Theresa P. Dela Rosa \\ Ilocos Sur Polytechnic State College, Philippines
}

\section{How to cite}

Garcia, M. T. T., \& Dela Rosa, M. T. P. (2021). Implementation of the Junior High School Mathematics Curriculum. Asia Pacific Journal on Curriculum Studies, 4(1), 25-48. https://doi.org/10.53420/apjcs.2021.3

\begin{abstract}
Uplifting the quality of education, the Department of Education pushed for the full implementation of the Enhanced Basic Education Program. The purpose of this study is to examine the status of implementation of the Junior High School Mathematics Curriculum in Ilocos Sur division during the school year 2017-2018. A questionnaire was used to gather the data from selected secondary schools in Ilocos Sur division. The data gathered were treated using mean, correlation analysis and multiple regression analysis. The overall rating of the status of the implementation of the Junior High School Mathematics Curriculum was perceived high. However, it was noted that some students were found weak in some content areas. Furthermore, the result revealed that the respondents considered the teachers' teaching methodologies and strategies significantly influenced the status of implementation of the Junior High School Mathematics Curriculum. Nevertheless, students found satisfactory in their levels of critical thinking and problem solving skills as they were not significantly influenced by the teachers' teaching methodologies and strategies. The findings of this study must be the basis of the school administrators and teachers to improve the levels of performances of the students.
\end{abstract}

Keywords: implementation, junior high school mathematics curriculum, critical thinking skills, problem solving skills

\section{Introduction}

The world is constantly changing as manifested by the influx of information across nations, and with all these inevitable changes, there is no better answer than equipping one's self with the power of education. Education has never failed anyone as an indispensable avenue in achieving success. It can provide opportunities for learners to explore, discover, understand and learn new things towards holistic development helping them meet global standards.

As part of the government effort to improve the quality of education in the country, the Department of education pushed for the full implementation of the Enhanced Basic Education Program which includes one year of kindergarten, six years of elementary education, and another six years of secondary education, broken down into four years Junior High School and two years Senior High School. This is to ensure that the curriculum is aligned to the changing needs of time, particularly the needs of the $21 \mathrm{st}$ century learners.

Under this curriculum, Mathematics as one of the core subjects is taught in spiral progression, that is, concepts are tackled from the simplest to the most complex one. The K to 12 Mathematics Curriculum Guide (2013) clearly states its goal which is to produce problem solvers and critical thinking learners. It also pervades life at any age, in any circumstance. Thus, its value goes beyond the classroom and the school. Therefore, Mathematics as a school subject must be learned critically and comprehensively.

As comprehensively discussed in a paper published by the Science Education Institute (under Department of Science and Technology) and Philippine Council of Mathematics Teacher Education (2011), Mathematics has the following roles in Philippine Education: facilitating participation in productive life activities, providing a way of making sense of the world, serving as a means of communication and operating as a gateway to national progress.

In Canada, the seven ministries of education (Alberta, British Columbia, Manitoba, Northwest Territories, Nunavut, Saskatchewan and Yukon Territory) in collaboration with teachers, administrators, parents, business representatives, postsecondary educators and others designed the Common Curriculum Framework. Under this curriculum, the main goals of 
Mathematics education are to prepare students to: a) use Mathematics confidently to solve problems, b) communicate and reason mathematically, c) appreciate and value Mathematics, d) make connections between Mathematics and its applications, e) commit themselves to lifelong learning, and f) become mathematically literate adults, using Mathematics to contribute to society. Eventually, students who have met these goals will gain understanding and appreciation of the contributions of Mathematics as a science, philosophy and art, exhibit a positive attitude toward Mathematics, engage and persevere in mathematical tasks and projects, contribute to mathematical discussions, take risks in performing mathematical tasks, and exhibit curiosity (Mathematics Kindergarten to Grade 9 Program of Studies, 2007).

According to the Curriculum Development Council in Hong Kong (Morris, 2014), Mathematics is valuable to help students develop the core competencies for lifelong learning. It is an integral part of the general education and hence a key learning area (KLA) of their school curriculum.

Moreover, students acquire knowledge and skills that will help them compete in the society of the 21 st century, which is an information age. To reflect the rapid growth of knowledge in the information age, Mathematics has unquestionably become a necessity for every individual to contribute towards the prosperity of the society. Mathematics pervades all aspects of life and it would be very difficult to live a normal life without making use of Mathematics of some kind. Many of the developments and decisions made in industry and commerce, the provision of social and community services as well as government policy and planning rely to some extent on the use of Mathematics.

Furthermore, Mathematics is essential in the school curriculum of Hong Kong (M0rris, 2014) as it is: a.) a powerful means of communication, b.) an analyzing tool for studying other disciplines, c.) an intellectual endeavor and a mode of thinking, and d.) a discipline, which can develop students' abilities to appreciate the beauty of nature, think logically and make sound judgments.

With the current trends in the Philippine Basic Education, particularly in Mathematics, the researcher wanted to examine the outcome of implementation of the Junior High School Mathematics curriculum along its content, contexts, skills and processes, values and attitudes, mathematical tools and the impact of the teaching-learning methodologies and strategies in the attainment of the major goals of Mathematics education.

The researcher believes that this can provide relevant insights to curriculum designers in the planning, implementation and monitoring of the new mathematics curriculum. The researcher also hopes to generate substantial information needed by school administrators and educators in order to identify the existing problems related to the implementation of the Junior High School Mathematics curriculum thus, providing interventions or solutions that will improve the quality of education.

\section{Literature review}

The 1987 Constitution of the Philippines, Article XIV, Section 1 orders that "The state shall protect and promote the right of all citizens to quality education at all levels and shall take appropriate steps to make such education accessible to all." Furthermore, Section 2 stipulates that "The state shall establish, maintain, and support a complete, adequate, and integrated system of education relevant to the needs of the people and society."

Looking from the same perspective, the Aquino administration felt the need to strengthen the backbone of the Philippine Basic Education and reiterated that quality education is a long-term solution to underemployment, malnutrition, and poverty. The creation of the $\mathrm{K}$ to 12 Basic Education Program is geared with relevant changes in order to produce Filipino graduates who are holistically-developed with 21 st century skills prepared for higher education, middle-level skills development, employment, and entrepreneurship.

They are characterized as graduates who possess healthy mind and body, have a solid moral and spiritual grounding, appreciate and care for humanity, the world, and environment, and are proud to be Filipinos (K to 12 Toolkit, 2012).

\section{Goals and roles of junior high school mathematics}

The rationale for studying Mathematics as a core subject is presented as: (a) Mathematics is a powerful means in a technologyoriented and information rich society to help students acquire the ability to communicate, explore, conjecture, reason logically and solve problems using a variety of methods. (b) Mathematics provides a means to acquire, organize and apply information, and plays an important role in communicating ideas through pictorial, graphical, symbolic, descriptive and analytical representations. Hence, Mathematics at the senior secondary level helps to lay a strong foundation for students' lifelong learning and provides a 
platform for the acquisition of new knowledge in this rapidly changing world. (c) Many of the developments, plans and decisions made in modern society rely, to some extent, on the use of measures, structures, patterns, shapes and the analysis of quantitative information. Therefore, mathematical experiences acquired at the senior secondary level enable students to become mathematically literate citizens who are more able to cope with the demands of the workplace. (d) Mathematics is a tool to help students enhance their understanding of the world. It provides a foundation for the study of other disciplines in the senior secondary and post-secondary education system. (e) Mathematics is an intellectual endeavor through which students can develop their imagination, initiative, creativity and flexibility of mind, as well as their ability to appreciate the beauty of nature.

Mathematics is a discipline which plays a central role in human culture.

In the Junior High School Mathematics Curriculum, the brief course description of Mathematics from K-10 is a skill subject. By itself, it is all about quantities, shapes and figures, functions, logic and reasoning. Mathematics is also a tool of science and a language complete with its own notations and symbols and "grammar" rules, with which concepts and ideas are effectively expressed.

In other words, the goal of Mathematics education is to develop a mathematically empowered citizenry which focuses on developing critical and analytical thinking skills among all Filipino students. Critical and analytical thinking encompass the following skills: Problem Solving, Communicating Mathematically, Reasoning and Making Mathematical Connections. The vision is to achieve the focus goal through the teaching of a solid mathematical content, the development of strong cognitive skills and the promotion of desirable cognitive values to all Filipino students no matter their background or circumstance.

As comprehensively discussed in a paper published by the Science Education Institute and Philippine Council of Mathematics Teacher Education (2011), Mathematics has the following roles in Philippine Education: facilitating participation in productive life activities, providing a way of making sense of the world, serving as a means of communication and operating as a gateway to national progress.

\section{Critical thinking skills}

The twin goals of Mathematics education are critical thinking and problem solving skills. These two goals are to be achieved with an organized and rigorous curriculum content, a well-defined set of high level skills and processes, desirable values and attitudes, and appropriate tools, recognizing as well the different contexts of Filipino learners (The K to 12 Mathematics Curriculum Guide, 2013).

Ubarre (2016) states that "critical thinking is the intellectually disciplined process of actively and skillfully conceptualizing, applying, analyzing, synthesizing, and/or evaluating information gathered from, or generated by, observation, experience, reflection, reasoning, or communication, as a guide to belief and action."

Critical thinking involves logic as well as creativity. It may involve inductive and deductive reasoning, analysis and problemsolving as well as creative, innovative and complex approaches to the resolution of issues and challenges.

The aim of critical thinking is to promote independent thinking, personal autonomy and reasoned judgment in thought and action. This involves two related dimensions: (1) the ability to reason well, and (2) the disposition to do so.

One of the significant aims of education is to produce learners who are well informed, that is to say, learners should understand ideas that are important, useful, beautiful and powerful. Another is to create learners who have the appetite to think analytically and critically, to use what they know to enhance their own lives and also to contribute to their society, culture and civilization.

These two aims for education as a vehicle to promote critical thinking are based on certain assumptions.

1. Brains are biological. Minds are created. Curriculum is thus a mind-altering device. This raises the moral requirement to treat learners as independent centers of consciousness with the fundamental ability to determine the contours of their own minds and lives.

2. Education should seek to prepare learners for self-direction and not pre-conceived roles. It is, therefore, essential that learners be prepared for thinking their way through the maze of challenges that life will present independently.

3. Education systems usually induct the neophyte into the forms-of-representation and realms of meaning which humans have created thus far.

4. Careful analysis, clear thinking, and reasoned deliberation are fundamental to democracy and democratic life. 
On the basis of these considerations the capacity for critical assessment and analysis emerges as fundamental for enjoying a good quality of life (The University of the West Indies, n.d.).

Furthermore, Facione, as mentioned by Alcantara \& Basca (2017), identified six cognitive skills as central to the concept of critical thinking. These skills are interpretation, analysis, explanation, evaluation, self-regulation and inference. Therefore, critical thinking skills are skills that enable one to analyse and synthesize information to solve problems.

\section{Problem solving skills}

Problem solving skills is one of the focal point in learning mathematics since this is a process in finding a way around a difficulty around an obstacle and finding solution to a problem that is unknown (The K to 12 Mathematics Curriculum Guide, 2013).

According to the National Council of Teachers of Mathematics, the term "problem solving" refers to mathematical tasks that have the potential to provide intellectual challenges for enhancing students' mathematical understanding and development. It plays an important role in Mathematics and should have a prominent role in the Mathematics education of K-12 students. However, knowing how to incorporate problem solving meaningfully into the Mathematics curriculum is not necessarily obvious to Mathematics teachers (Brown \& Nanny, 2003).

Of all school subjects, Mathematics introduces and develops the "problem-solving" concept, as fundamental component of school learning with a strong formative effect on students. In Mathematics, solving problems represents the most effective concept to contextualization and re-contextualization of concepts, to operational and basic mathematical knowledge transfer to ensure a sustainable and meaningful learning. The resolvent conduct of the student also involves, in addition to the cognitive factors, factors aiming the affectivity and the experience of the student (Capriora, 2015).

\section{Objectives}

This study assessed the status of implementation of the Junior High School Mathematics Curriculum in selected Secondary Schools in the Division of Ilocos Sur.

Specifically, it sought to answer the following questions:

1. What is the status of implementation of the Junior High School Mathematics curriculum as assessed by administrators, teachers, and students along:
a. content,
b. contexts,
c. skills and processes,
d. values and attitudes, and
e. mathematical tools?

2. What is the teacher's extent of use of the following teaching-learning methodologies and strategies in the teaching of Junior High School Mathematics Curriculum:
a. cooperative learning,
b. constructivism,
c. reflective learning,
d. experiential and situated learning, and
e. discovery and inquiry-based learning?

3. What are the Grade 9 students' levels of critical thinking and problem-solving skills?

4. Is there a significant relationship between the status of implementation of the Junior High School Mathematics Curriculum and the teaching-learning methodologies and strategies?

5. Are the levels of the students' critical thinking and problem-solving skills significantly influenced by the teachinglearning methodologies and strategies?

\section{Time and place}

This study was conducted at the Department of Education, selected secondary schools at SDO Ilocos Sur covering the academic Year 2017-2018. 


\section{Methods}

\section{Research design}

This study used the descriptive-evaluative research design. Descriptive method was employed to assess the status of implementation of the Junior High School Mathematics Curriculum along content, contexts, skills and processes, values and attitudes, and mathematical tools together with teacher's extent of use of the teaching-learning methodologies and strategies in the teaching of Junior High School Mathematics curriculum through questionnaires.

Evaluative method was used to assess the level of influence of the teaching-learning methodologies and strategies on the status of implementation of the Junior High School Mathematics Curriculum and the levels of the students' critical thinking and problemsolving skills.

\section{Population and locale}

Among the 62 secondary schools in the Schools Division of Ilocos Sur, the researcher made used of random sampling in selecting its respondents. Total enumeration was employed for the number of school heads and Mathematics teachers as respondents. Considering the large number of Grade 9 students, the Power Analysis was used to determine the sample needed in this study.

Table 1

Distribution of the Respondents of the Study

\begin{tabular}{|l|c|c|c|c|}
\hline Secondary Schools & Administrators & Teachers & \multicolumn{2}{|l|}{ Students } \\
\hline & N & N & N & n \\
\hline Banayoyo NHS & 1 & 2 & 120 & 20 \\
\hline Bantay NHS & 1 & 1 & 108 & 18 \\
\hline Belen NHS & 1 & 1 & 43 & 8 \\
\hline Burgos NHS & 1 & 2 & 195 & 34 \\
\hline Cabittaogan NHS & 1 & 1 & 60 & 10 \\
\hline Lussoc NHS & 1 & 1 & 198 & 34 \\
\hline Manzante NHS & 1 & 1 & 39 & 6 \\
\hline Naglaoa-an NHS & 1 & 1 & 97 & 16 \\
\hline Narvacan NCHS & 1 & 3 & 521 & 88 \\
\hline Puro NHS, Caoayan & 1 & 1 & 24 & 4 \\
\hline Rancho NHS & 1 & 1 & 23 & 4 \\
\hline San Emilio NHS & 1 & 1 & 12 & 2 \\
\hline San Esteban NHS & 1 & 1 & 112 & 20 \\
\hline San Vicente IS & 1 & 1 & 81 & 14 \\
\hline Santa Maria NHS & 1 & 2 & 328 & 56 \\
\hline Sigay NHS & 1 & 1 & 30 & 6 \\
\hline Solotsolot NHS & 1 & 1 & 67 & 12 \\
\hline Suyo NHS (Annex) & 1 & 1 & 22 & 4 \\
\hline Tay-ac NHS & 1 & 1 & 59 & 10 \\
\hline Teodoro Hernaez NHS & 1 & 2 & 259 & 44 \\
\hline Total & 20 & 26 & 2398 & 408 \\
\hline
\end{tabular}

\section{Research instrument}

This study used questionnaire as its main data gathering tool. The questionnaire is divided into three parts. Part I pertains to the status of implementation of the Junior High School Mathematics curriculum along (a) content, (b) contexts, (c) skills and processes, (d) values and attitudes; and (e) mathematical tools. Items on content, contexts, skills and processes, and values and attitudes were based from The K to 12 Mathematics Curriculum Guide (2013), while items for mathematical tools were based 
from the study of Ubarre (2016); Part II elicited the teaching-learning methodologies and strategies used by the teachers. Most of the items were constructed by the researcher and validated by experts, while some of the items were taken from the study of Avila (2016). The items pertaining to the teaching-learning methodologies and strategies were grouped together for ease of administration and to facilitate the organization of data. The items pertaining to the characteristics of a Cooperative Learning are 1 to 5; Constructivism, 6 to 10; Reflective Learning, 11 to 15; Experiential Learning and Situated Learning, 16 to 23; Discovery Learning and Inquiry-Based Learning, 23 to 33, respectively. Part III was the achievement test taken from the Learner's Material for Mathematics Grade 9 (2014) for the student-respondents to assess their critical thinking and problem-solving skills. It is a 50item multiple choice test consisting of the five learning areas. Items 1-10 were taken from Numbers and Number Sense; Measurement, 11-20; Patterns and Algebra, 21-30; Geometry, 31-40; Trigonometry, 41-50. Pilot testing was done to determine the items to be retained, revised and rejected. The computed Cronbach's alpha of 0.75 described as "Very High" indicates that the items are consistent and reliable.

All the items of the questionnaire were subjected to content validation by five experts in the field of Mathematics. The computed mean value of 5.00 for Parts I and II, and 4.87 for Part III revealed that the validity of the questionnaire is "Very High."

Parts I and II of the questionnaire were common among the respondents. Part III was for the Grade 9 students only.

\section{Data gathering procedure}

During the conduct of the study, the researcher asked permission from the Schools Division Superintendent in the Schools Division of Ilocos Sur. As soon as the request was granted, the researcher coordinated with the heads and distributed the questionnaires to the selected secondary schools.

The questionnaires were retrieved and tallied. Gathered data were subjected to statistical analysis for the basis of interpretation and drawing out significant conclusions.

\section{Statistical treatment of data}

Data collected were analyzed and interpreted using the following statistical tools:

Mean was used to examine the status of implementation of the Junior High School Mathematics Curriculum along content, contexts, skills and processes, values and attitudes, and mathematical tools; the level of implementation of the teaching-learning methodologies and strategies - employed by teachers of Junior High School Mathematics curriculum - cooperative learning, constructivism, reflective learning, experiential and situated learning, and discovery and inquiry-based learning; and the levels of critical thinking and problem solving skills of the Grade 9 students in the selected secondary schools in the Division of Ilocos Sur.

Correlation analysis was used to determine the significant relationship of the status of implementation of the Junior High School Mathematics Curriculum and the level of implementation of the teaching -learning methodologies and strategies; and

Multiple Regression was used to detect the significant influence of the teaching-learning methodologies and strategies on the Grade 9 students' levels of critical thinking and problem-solving skills.

\section{Results and Discussion}

The mean ratings showing the status of implementation of the Junior High School Mathematics Curriculum along Content Standards as assessed by the administrators, teachers and students of selected schools in the division of Ilocos Sur is presented in Table 2 . 
Table 2

Item Mean Ratings Showing the Status of the Junior High School Mathematics Curriculum along Content Standards as Assessed by the Administrators, Teachers and Students of Selected Schools in the Division of Ilocos Sur

\begin{tabular}{|c|c|c|c|c|c|c|c|c|}
\hline \multirow{2}{*}{ Content Standards } & \multicolumn{2}{|c|}{ Admin } & \multicolumn{2}{|c|}{ Teachers } & \multicolumn{2}{|c|}{ Students } & \multicolumn{2}{|c|}{ As a whole } \\
\hline & $\bar{x}$ & DR & $\overline{\mathbf{X}}$ & DR & $\bar{x}$ & DR & $\bar{x}$ & DR \\
\hline \multicolumn{9}{|l|}{$\begin{array}{l}\text { NUMBER AND NUMBER } \\
\text { SENSE }\end{array}$} \\
\hline $\begin{array}{l}\text { 1. key concepts of sets and real } \\
\text { number system }\end{array}$ & 4.65 & $\mathrm{FuC}$ & 4.15 & $\mathrm{MuC}$ & 4.02 & $\mathrm{MuC}$ & 4.28 & $\mathrm{FuC}$ \\
\hline \multicolumn{9}{|l|}{ MEASUREMENT } \\
\hline 2. key concepts of measurements & 4.25 & $\mathrm{FuC}$ & 4.04 & $\mathrm{MuC}$ & 3.83 & $\mathrm{MuC}$ & 4.04 & $\mathrm{MuC}$ \\
\hline \multicolumn{9}{|l|}{ GEOMETRY } \\
\hline $\begin{array}{l}\text { 3. key concepts of geometry of } \\
\text { shapes and sizes, and geometric } \\
\text { relationship }\end{array}$ & 4.20 & $\mathrm{MuC}$ & 4.08 & $\mathrm{MuC}$ & 3.79 & $\mathrm{MuC}$ & 4.02 & $\mathrm{MuC}$ \\
\hline $\begin{array}{l}\text { 4. key concepts of logic and } \\
\text { reasoning }\end{array}$ & 3.55 & $\mathrm{MuC}$ & 3.54 & $\mathrm{MuC}$ & 3.33 & $\mathrm{MoC}$ & 3.47 & $\mathrm{MuC}$ \\
\hline $\begin{array}{l}\text { 5. key concepts of axiomatic } \\
\text { structure of geometry and } \\
\text { triangle congruence }\end{array}$ & 3.60 & $\mathrm{MuC}$ & 3.62 & $\mathrm{MuC}$ & 3.33 & $\mathrm{MoC}$ & 3.51 & $\mathrm{MuC}$ \\
\hline $\begin{array}{l}\text { 6. key concepts of quadrilaterals } \\
\text { and triangle similarity }\end{array}$ & 4.00 & $\mathrm{MuC}$ & 4.12 & $\mathrm{MuC}$ & 3.64 & $\mathrm{MuC}$ & 3.92 & $\mathrm{MuC}$ \\
\hline 7. basic concepts of trigonometry & 3.90 & $\mathrm{MuC}$ & 3.58 & $\mathrm{MuC}$ & 3.37 & $\mathrm{MoC}$ & 3.62 & $\mathrm{MuC}$ \\
\hline $\begin{array}{l}\text { 8. key concepts of circles and } \\
\text { coordinate geometry }\end{array}$ & 4.00 & $\mathrm{MuC}$ & 3.85 & $\mathrm{MuC}$ & 3.66 & $\mathrm{MuC}$ & 3.84 & $\mathrm{MuC}$ \\
\hline Mean & 3.88 & $\mathbf{H}$ & 3.80 & $\mathbf{H}$ & 3.52 & $\mathbf{H}$ & 3.73 & $\mathbf{H}$ \\
\hline \multicolumn{9}{|l|}{ PATTERNS AND ALGEBRA } \\
\hline $\begin{array}{|lll|}\text { 9. } \begin{array}{l}\text { algebraic expressions and } \\
\text { equations }\end{array} & \\
\end{array}$ & 4.50 & $\mathrm{FuC}$ & 4.50 & $\mathrm{FuC}$ & 4.15 & $\mathrm{MuC}$ & 4.38 & $\mathrm{FuC}$ \\
\hline $\begin{array}{l}\text { 10. properties of real numbers as } \\
\text { applied in linear equations and } \\
\text { inequalities in one variable }\end{array}$ & 4.45 & $\mathrm{FuC}$ & 4.35 & $\mathrm{FuC}$ & 3.94 & $\mathrm{MuC}$ & 4.25 & $\mathrm{FuC}$ \\
\hline 11. factors of polynomials & 4.50 & $\mathrm{FuC}$ & 4.31 & $\mathrm{FuC}$ & 4.24 & $\mathrm{FuC}$ & 4.35 & $\mathrm{FuC}$ \\
\hline 12. rational algebraic expressions & 4.35 & FuC & 4.12 & $\mathrm{MuC}$ & 4.02 & $\mathrm{MuC}$ & 4.16 & $\mathrm{MuC}$ \\
\hline $\begin{array}{l}\text { 13. linear equations and inequalities } \\
\text { in two variables }\end{array}$ & 4.20 & $\mathrm{MuC}$ & 408 & $\mathrm{MuC}$ & 3.86 & $\mathrm{MuC}$ & 4.04 & $\mathrm{MuC}$ \\
\hline $\begin{array}{l}\text { 14. systems of linear equations and } \\
\text { inequalities in two variables }\end{array}$ & 4.15 & $\mathrm{MuC}$ & 4.00 & $\mathrm{MuC}$ & 3.80 & $\mathrm{MuC}$ & 3.98 & $\mathrm{MuC}$ \\
\hline 15. linear functions & 4.45 & $\mathrm{FuC}$ & 4.27 & $\mathrm{FuC}$ & 4.05 & $\mathrm{MuC}$ & 4.26 & $\mathrm{FuC}$ \\
\hline \begin{tabular}{|lll}
$\begin{array}{l}\text { 16. quadratic equations and } \\
\text { functions }\end{array}$ & \\
\end{tabular} & 4.55 & $\mathrm{FuC}$ & 4.31 & $\mathrm{FuC}$ & 4.13 & $\mathrm{MuC}$ & 4.33 & $\mathrm{FuC}$ \\
\hline 17. variation and radicals & 4.40 & $\mathrm{FuC}$ & 4.38 & $\mathrm{FuC}$ & 3.85 & $\mathrm{MuC}$ & 4.21 & $\mathrm{FuC}$ \\
\hline 18. sequences & 4.45 & $\mathrm{FuC}$ & 4.00 & $\mathrm{MuC}$ & 4.02 & $\mathrm{MuC}$ & 4.16 & $\mathrm{MuC}$ \\
\hline $\begin{array}{l}\text { 19. polynomial equations and } \\
\text { functions }\end{array}$ & 4.30 & $\mathrm{FuC}$ & 3.81 & $\mathrm{MuC}$ & 4.09 & $\mathrm{MuC}$ & 4.07 & $\mathrm{MuC}$ \\
\hline Mean & 4.39 & $\mathbf{H}$ & 4.19 & $\mathbf{H}$ & 4.01 & $\mathbf{H}$ & 4.20 & $\mathbf{H}$ \\
\hline \multicolumn{9}{|l|}{$\begin{array}{l}\text { STATISTICS AND } \\
\text { PROBABILITY }\end{array}$} \\
\hline \begin{tabular}{|l}
20. \\
$\begin{array}{l}\text { uses and importance of } \\
\text { Statistics }\end{array}$
\end{tabular} & 3.85 & $\mathrm{MuC}$ & 3.54 & $\mathrm{MuC}$ & 3.31 & $\mathrm{MoC}$ & 3.57 & $\mathrm{MuC}$ \\
\hline 21. measures of central tendency & 3.80 & $\mathrm{MuC}$ & 3.46 & $\mathrm{MuC}$ & 3.19 & $\mathrm{MoC}$ & 3.48 & $\mathrm{MuC}$ \\
\hline 22. measures of variability & 3.60 & $\mathrm{MuC}$ & 3.23 & $\mathrm{MoC}$ & 3.18 & $\mathrm{MoC}$ & 3.34 & $\mathrm{MoC}$ \\
\hline 23. probability & 3.50 & $\mathrm{MuC}$ & 3.31 & $\mathrm{MoC}$ & 3.15 & $\mathrm{MoC}$ & 3.32 & $\mathrm{MoC}$ \\
\hline 24. combinations & 3.55 & $\mathrm{MuC}$ & 3.23 & $\mathrm{MoC}$ & 3.11 & $\mathrm{MoC}$ & 3.30 & $\mathrm{MoC}$ \\
\hline 25. measures of position & 3.40 & $\mathrm{MoC}$ & 3.08 & $\mathrm{MoC}$ & 3.07 & $\mathrm{MoC}$ & 3.18 & $\mathrm{MoC}$ \\
\hline Mean & 3.62 & $\mathbf{H}$ & 3.31 & $\mathbf{F}$ & 3.17 & $\mathbf{F}$ & 3.37 & $\mathbf{F}$ \\
\hline Item DR & & & & Derall & & & & \\
\hline $\begin{array}{l}\text { Fully Attained } \\
\text { Much Covered } \\
\text { Moderately Co } \\
\text { Fairly Covered } \\
\text { Not Covered ( }\end{array}$ & $\begin{array}{l}(\mathrm{FuC}) \\
(\mathrm{MuC}) \\
\text { vered }(\mathrm{N} \\
(\mathrm{FaC}) \\
\mathrm{NC})\end{array}$ & (1oC) & $\begin{array}{l}\mathrm{He} \\
\mathrm{Fa} \\
\mathrm{Lo} \\
\mathrm{Ve}\end{array}$ & $\begin{array}{l}\text { ry High } \\
\text { gh }(\mathrm{H}) \\
\text { r (F) } \\
\text { w (L) } \\
\text { ry Low }\end{array}$ & H) & & & \\
\hline
\end{tabular}


Based from Table 2, the values directly state that all concepts and lessons under Number and Number Sense have been thoroughly discussed. Lessons are discussed in the beginning of the school year where class interruptions are very minimal. Thus, this may imply that this content area has been mastered by the learners. This conforms to the findings of Alcantara \& Basca (2017) that students find mastering the competencies in Number and Number Sense with least extent of difficulty.

The said findings are supported by Cruz (2010) stating that K-12 students are studying more mathematics, often at an early grade, with a focus of conceptual understanding as well as skill development and problem solving.

Along Measurement, the result implies that the learners are able to demonstrate understanding and mastery of important concepts. The learners are able to master the competencies with least extent of difficulty (Alcantara \& Basca, 2017). Measurement is even taught in other subject areas such as Science and TLE. This can greatly contribute to the mastery of lessons since it has continuation/re-discussion from other subjects.

Furthermore, the data from Table 2 implies that Geometry has been well-understood by the learners because of its practicality in real life situations and also it has been one of the central content area in lower grade level. This is supported by the study of Ballerta (2016) that the students of Ilocos Sur National High School had a "Good" level of performance in Geometry particularly in Geometric Relations. There existed significant differences in the level of performance in Geometry among the respondents, specifically on Geometric Relations and Congruent Triangles.

Moreover, Lacorte (2014) found that all types of science high schools in the Philippines demonstrated better performance in Geometry but weak performance in Calculus.

Similar findings also revealed in the study of Jimenez (2012) where the third-year high school students grouped heterogeneously in Candon National High School during the school year 2011-2012 showed a "Satisfactory" level of achievement in Geometry.

However, it should also be noted that there is a need for reinforcement in content standards that are nearly assessed as "Moderately Covered" particularly in standards dealing with proofs.

Meanwhile, the content standards of Patterns and Algebra are also met as manifested from the table. This confirms the findings of Espejo (2011) that the highest performance of the first year students in Candon National High School is on Algebra.

Lastly, Table 2 also reveals the mean ratings of the status of implementation of the Junior High School Mathematics curriculum along Statistics and Probability. The result implies that this is a content area which is less covered compared to other content areas since this is placed last in the curriculum. Only few of these lessons were discussed due to numerous activities conducted during the latter quarters of the school year.

It can be seen from the data that almost all of the content standards included in Statistics and Probability are "Moderately Covered," especially the last four topics. The indicated topics were not fully discussed due to successive school activities or extracurricular activities held during the quarter. These lessons need to be discussed thoroughly since they require careful and critical analysis. This supports the claim of Atlantic Evaluation Research Consultants (2008) that covering all the topics added by diverse students' needs and abilities seemed to affect the delivery of the curriculum particularly students' learning.

Scrutiny of Table 3 shows that the respondents as a whole rated the status of implementation of the Junior High School curriculum "High" along contexts as indicated by the overall mean rating of 4.02 .

The results show that despite few complexities in the subject, the contextual benefits are given much importance and are integrated in every lesson covered. All the contents enveloped in the Mathematics curriculum are accomplished. 
Table 3

Mean Ratings Showing the Status of the Junior High School Mathematics Curriculum along Contexts as Assessed by the Administrators, Teachers and Students of Selected Schools in the Division of Ilocos Sur

\begin{tabular}{|c|c|c|c|c|c|c|c|c|}
\hline Items & \multicolumn{2}{|c|}{ Admin } & \multicolumn{2}{|c|}{ Teachers } & \multicolumn{2}{|c|}{ Students } & \multicolumn{2}{|c|}{ As a whole } \\
\hline The curriculum & $\overline{\bar{X}}$ & DR & $\overline{\bar{X}}$ & DR & $\overline{\bar{X}}$ & DR & $\overline{\mathrm{X}}$ & $\mathrm{DR}$ \\
\hline $\begin{array}{l}\text { 1. integrates new concepts into } \\
\text { existing mental frameworks. }\end{array}$ & 4.20 & $\mathrm{MuA}$ & 3.85 & $\mathrm{MuA}$ & 3.54 & $\mathrm{MuA}$ & 3.86 & $\mathrm{MuA}$ \\
\hline $\begin{array}{l}\text { 2. provides the students with a } \\
\text { variety of learning } \\
\text { experiences. }\end{array}$ & 4.30 & $\mathrm{FuA}$ & 4.15 & $\mathrm{MuA}$ & 3.82 & $\mathrm{MuA}$ & 4.09 & $\mathrm{MuA}$ \\
\hline $\begin{array}{l}\text { 3. designs learning } \\
\text { experiences suited to different } \\
\text { kinds of students. }\end{array}$ & 4.25 & $\mathrm{FuA}$ & 4.00 & $\mathrm{MuA}$ & 3.64 & $\mathrm{MuA}$ & 3.96 & $\mathrm{MuA}$ \\
\hline $\begin{array}{l}\text { 4. considers Mathematics } \\
\text { learning as an active and } \\
\text { constructive process. }\end{array}$ & 4.35 & $\mathrm{FuA}$ & 4.19 & $\mathrm{MuA}$ & 3.80 & $\mathrm{MuA}$ & 4.11 & $\mathrm{MuA}$ \\
\hline $\begin{array}{l}\text { 5. provides standards of } \\
\text { expectations that are clear with } \\
\text { ongoing assessment and } \\
\text { feedback. }\end{array}$ & 4.20 & $\mathrm{MuA}$ & 3.92 & $\mathrm{MuA}$ & 3.69 & $\mathrm{MuA}$ & 3.94 & $\mathrm{MuA}$ \\
\hline $\begin{array}{l}\text { 6. provides lessons that can } \\
\text { motivate the students to learn. }\end{array}$ & 4.40 & $\mathrm{FuA}$ & 4.23 & $\mathrm{FuA}$ & 3.96 & $\mathrm{MuA}$ & 4.20 & $\mathrm{MuA}$ \\
\hline $\begin{array}{l}\text { 7. provides a sense of } \\
\text { belongingness and encourage } \\
\text { risk taking. }\end{array}$ & 4.15 & $\mathrm{MuA}$ & 4.00 & $\mathrm{MuA}$ & 3.77 & $\mathrm{MuA}$ & 3.97 & $\mathrm{MuA}$ \\
\hline $\begin{array}{l}\text { 8. provides opportunity for } \\
\text { success for the development } \\
\text { and maintenance of positive } \\
\text { attitudes and self-confidence. }\end{array}$ & 4.30 & $\mathrm{FuA}$ & 4.12 & $\mathrm{MuA}$ & 3.85 & $\mathrm{MuA}$ & 4.09 & $\mathrm{MuA}$ \\
\hline $\begin{array}{l}\text { 9. values and respects all } \\
\text { students experiences and } \\
\text { ways of thinking. }\end{array}$ & 4.40 & $\mathrm{FuA}$ & 4.38 & $\mathrm{FuA}$ & 3.90 & $\mathrm{MuA}$ & 4.23 & FuA \\
\hline $\begin{array}{l}\text { 10. develops students } \\
\text { capability to use Mathematics } \\
\text { confidently to solve problems. }\end{array}$ & 4.30 & $\mathrm{FuA}$ & 4.00 & $\mathrm{MuA}$ & 3.91 & $\mathrm{MuA}$ & 4.07 & $\mathrm{MuA}$ \\
\hline $\begin{array}{l}\text { 11. provides opportunities to } \\
\text { read about, represents, views, } \\
\text { write about, listen to and } \\
\text { discuss mathematical ideas. }\end{array}$ & 4.10 & $\mathrm{MuA}$ & 4.08 & $\mathrm{MuA}$ & 3.83 & $\mathrm{MuA}$ & 4.00 & MuA \\
\hline $\begin{array}{l}\text { 12. makes connections } \\
\text { between Mathematics and its } \\
\text { application, communicates } \\
\text { and reasons mathematically. }\end{array}$ & 4.30 & $\mathrm{FuA}$ & 4.04 & $\mathrm{MuA}$ & 3.75 & $\mathrm{MuA}$ & 4.03 & $\mathrm{MuA}$ \\
\hline $\begin{array}{l}\text { 13. recognizes multi-cultural } \\
\text { background of students when } \\
\text { providing learning } \\
\text { opportunities. }\end{array}$ & 4.10 & $\mathrm{MuA}$ & 3.77 & $\mathrm{MuA}$ & 3.56 & $\mathrm{MuA}$ & 3.81 & $\mathrm{MuA}$ \\
\hline $\begin{array}{l}14 \text { develops cultural } \\
\text { competence in working with } \\
\text { others by recognizing and } \\
\text { respecting } \\
\text { differences. }\end{array}$ & 4.00 & $\mathrm{MuA}$ & 3.96 & $\mathrm{MuA}$ & 3.62 & $\mathrm{MuA}$ & 3.86 & $\mathrm{MuA}$ \\
\hline $\begin{array}{l}\text { 15. provides gender-fair } \\
\text { opportunities for learning. }\end{array}$ & 4.20 & $\mathrm{MuA}$ & 4.27 & $\mathrm{FuA}$ & 3.83 & $\mathrm{MuA}$ & 4.10 & $\mathrm{MuA}$ \\
\hline Overall & 4.24 & VH & 4.06 & $\mathbf{H}$ & 3.76 & H & 4.02 & H \\
\hline $\begin{array}{l}\text { Norm: } \\
4.21-5.00 \\
3.41-4.20 \\
2.61-3.40 \\
1.81-2.60 \\
1.00-1.80\end{array}$ & $\begin{array}{l}\text { Item I } \\
\text { Attaine } \\
\text { Attaine } \\
\text { rately A } \\
\text { Attaine } \\
\text { ttained }\end{array}$ & $\begin{array}{l}\text { (FuA) } \\
(\mathrm{MuA}) \\
\text { ained }(\mathrm{M} \\
\text { (FaA) } \\
\mathrm{NA})\end{array}$ & A) & $\begin{array}{l}\text { Ove } \\
\text { Very } \\
\text { High } \\
\text { Fair } \\
\text { Low } \\
\text { Very }\end{array}$ & $\begin{array}{l}11 \mathrm{DR} \\
\text { ligh (V } \\
\text { H) }\end{array}$ & & & \\
\hline
\end{tabular}


Table 4 presents the status of implementation of the Junior High School Mathematics Curriculum along skills and processes.

Table 4

Mean Ratings Showing the Status of the Junior High School Mathematics Curriculum along Skills and Processes as Assessed by the Administrators, Teachers and Students of Selected Schools in the Division of Ilocos Sur

\begin{tabular}{|c|c|c|c|c|c|c|c|c|}
\hline Skills and Processes & \multicolumn{2}{|c|}{ Admin } & \multicolumn{2}{|c|}{ Teachers } & \multicolumn{2}{|c|}{ Students } & \multicolumn{2}{|c|}{ As a whole } \\
\hline The learner... & $\overline{\mathbf{X}}$ & DR & $\overline{\mathbf{x}}$ & DR & $\overline{\mathbf{X}}$ & DR & $\overline{\mathbf{x}}$ & DR \\
\hline $\begin{array}{l}\text { 1. formulates challenging situations } \\
\text { involving sets and real numbers and } \\
\text { solve these in a variety of strategies. }\end{array}$ & 3.80 & $\mathrm{MuA}$ & 3.69 & $\mathrm{MuA}$ & 3.74 & MuA & 3.74 & $\mathrm{MuA}$ \\
\hline $\begin{array}{l}\text { 2. formulates real-life problems } \\
\text { involving measurements and solve } \\
\text { these problems in a variety of } \\
\text { strategies. }\end{array}$ & 4.10 & $\mathrm{MuA}$ & 3.77 & $\mathrm{MuA}$ & 3.70 & $\mathrm{MuA}$ & 3.86 & MuA \\
\hline $\begin{array}{l}\text { 3. creates models of plane figures } \\
\text { and formulate and solve accurately } \\
\text { authentic problems involving sides } \\
\text { and angles of a polygon. }\end{array}$ & 3.90 & $\mathrm{MuA}$ & 3.73 & MuA & 3.51 & $\mathrm{MuA}$ & 3.71 & $\mathrm{MuA}$ \\
\hline $\begin{array}{l}\text { 4. communicates mathematical } \\
\text { thinking with coherence and clarity } \\
\text { in formulating and analyzing } \\
\text { arguments. }\end{array}$ & 3.80 & $\mathrm{MuA}$ & 3.73 & $\mathrm{MuA}$ & 3.40 & MoA & 3.64 & $\mathrm{MuA}$ \\
\hline $\begin{array}{l}\text { 5. formulates an organized plan to } \\
\text { handle a real-life situation. }\end{array}$ & 3.65 & $\mathrm{MuA}$ & 3.81 & MuA & 3.60 & $\mathrm{MuA}$ & 3.69 & $\mathrm{MuA}$ \\
\hline $\begin{array}{l}\text { 6. communicates mathematical } \\
\text { thinking with coherence and clarity } \\
\text { in formulating, investigating, } \\
\text { analyzing, and solving real-life } \\
\text { problems involving congruent } \\
\text { triangles using appropriate and } \\
\text { accurate representations. }\end{array}$ & 3.75 & MuA & 3.69 & $\mathrm{MuA}$ & 3.52 & $\mathrm{MuA}$ & 3.65 & $\mathrm{MuA}$ \\
\hline $\begin{array}{l}\text { 7. investigates, analyzes, and solves } \\
\text { problems involving quadrilaterals } \\
\text { (parallelograms, trapezoids, kites) } \\
\text { and triangle similarity through } \\
\text { appropriate } \\
\text { representation. }\end{array}$ & 4.00 & $\mathrm{MuA}$ & 3.81 & $\mathrm{MuA}$ & 3.62 & $\mathrm{MuA}$ & 3.81 & $\mathrm{MuA}$ \\
\hline $\begin{array}{l}\text { 8. applies concepts of trigonometric } \\
\text { ratios to formulate and solve real-life } \\
\text { problems with precision and } \\
\text { accuracy. }\end{array}$ & 3.85 & MuA & 3.50 & $\mathrm{MuA}$ & 3.32 & MoA & 3.56 & $\mathrm{MuA}$ \\
\hline $\begin{array}{l}\text { 9. formulates and find solutions to } \\
\text { challenging situation involving } \\
\text { circles and other related terms in } \\
\text { different disciplines } \\
\begin{array}{lcr}\text { appropriate through } \\
\text { representations. }\end{array} \\
\end{array}$ & 3.95 & $\mathrm{MuA}$ & 3.62 & $\mathrm{MuA}$ & 3.46 & $\mathrm{MuA}$ & 3.68 & $\mathrm{MuA}$ \\
\hline $\begin{array}{l}\text { 10. formulates and solve problems } \\
\text { involving geometric figures on the } \\
\text { rectangular coordinate plane with } \\
\text { perseverance and accuracy. }\end{array}$ & 3.75 & $\mathrm{MuA}$ & 3.58 & $\mathrm{MuA}$ & 3.53 & $\mathrm{MuA}$ & 3.62 & $\mathrm{MuA}$ \\
\hline $\begin{array}{l}\text { 11. models situations using oral, } \\
\text { written, graphical, algebraic } \\
\text { methods in solving problems } \\
\text { involving algebraic expressions, } \\
\text { linear equations, and inequalities in } \\
\text { one variable. }\end{array}$ & 3.85 & $\mathrm{MuA}$ & 3.65 & $\mathrm{MuA}$ & 3.54 & $\mathrm{MuA}$ & 3.68 & $\mathrm{MuA}$ \\
\hline
\end{tabular}




\begin{tabular}{|c|c|c|c|c|c|c|c|c|}
\hline $\begin{array}{l}\text { 12. formulates real-life problems } \\
\text { involving factors of polynomials, } \\
\text { rational algebraic expressions, linear } \\
\text { equations and inequalities in two } \\
\text { variables, systems of linear } \\
\text { equations and inequalities in two } \\
\text { variables and linear functions, and } \\
\text { solve these problems accurately } \\
\text { using a variety of strategies. }\end{array}$ & 3 & $\mathrm{MuA}$ & 3.62 & $\mathrm{MuA}$ & 3.57 & $\mathrm{MuA}$ & 3.71 & $\mathrm{MuA}$ \\
\hline $\begin{array}{l}\text { 13. formulates and solves accurately } \\
\text { real-life problems involving linear } \\
\text { inequalities in two variables, } \\
\text { systems of linear inequalities in two } \\
\text { variables, and linear functions. }\end{array}$ & 3.65 & MuA & 3.54 & MuA & 3.46 & MuA & 3.55 & $\mathrm{MuA}$ \\
\hline $\begin{array}{l}14 \text { investigates thoroughly } \\
\text { mathematical relationships in } \\
\text { various situations, formulate real-life } \\
\text { problems involving quadratic } \\
\text { equations, inequalities and } \\
\text { functions, rational algebraic } \\
\text { equations and solve them using a } \\
\text { variety of strategies. }\end{array}$ & 3.85 & $\mathrm{MuA}$ & 3.73 & $\mathrm{MuA}$ & 3.49 & $\mathrm{MuA}$ & 3.69 & $\mathrm{MuA}$ \\
\hline \begin{tabular}{|l|} 
15. formulates and solve accurately \\
problems involving radicals.
\end{tabular} & 3.75 & $\mathrm{MuA}$ & 3.73 & MuA & 3.48 & MuA & 3.65 & $\mathrm{MuA}$ \\
\hline 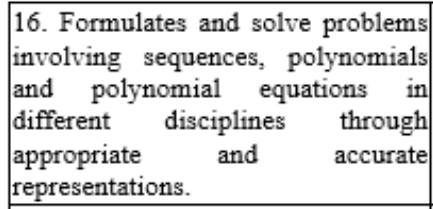 & 4.20 & MuA & 3.65 & MuA & 3.64 & $\mathrm{MuA}$ & 3.83 & $\mathrm{MuA}$ \\
\hline $\begin{array}{|lr|}17 . \quad \text { conducts } & \text { systematically a } \\
\text { mathematical } & \text { investigation } \\
\text { involving polynomial } & \text { functions in } \\
\text { different fields. } & \\
\end{array}$ & 3.80 & MuA & 3.50 & $\mathrm{MuA}$ & 3.44 & MuA & 3.58 & $\mathrm{MuA}$ \\
\hline $\begin{array}{l}\text { 18. collects and organizes data } \\
\text { systematically and compute } \\
\text { accurately measures of central } \\
\text { tendency and variability and apply } \\
\text { this appropriately in data analysis } \\
\text { and interpretation in different fields. }\end{array}$ & 3.95 & MuA & 3.50 & $\mathrm{MuA}$ & 3.40 & MoA & 3.62 & $\mathrm{MuA}$ \\
\hline $\begin{array}{l}\text { 19. formulates and solves practical } \\
\text { problems involving probability of } \\
\text { simple events. }\end{array}$ & 3.70 & $\mathrm{MuA}$ & 3.38 & MoA & 3.41 & $\mathrm{MuA}$ & 3.50 & $\mathrm{MuA}$ \\
\hline $\begin{array}{l}\text { 20. uses precise counting technique } \\
\text { and probability in formulating } \\
\text { conclusions and making decisions. }\end{array}$ & 3.90 & $\mathrm{MuA}$ & 3.31 & MoA & 3.48 & $\mathrm{MuA}$ & 3.56 & $\mathrm{MuA}$ \\
\hline $\begin{array}{l}\text { 21. conducts systematically a mini- } \\
\text { research applying the different } \\
\text { statistical methods. }\end{array}$ & 3.65 & $\mathrm{MuA}$ & 3.08 & MoA & 3.26 & MoA & 3.33 & MoA \\
\hline Overall & 3.85 & $\mathbf{H}$ & 3.60 & $\mathbf{H}$ & 3.50 & $\mathbf{H}$ & 3.65 & $\mathbf{H}$ \\
\hline 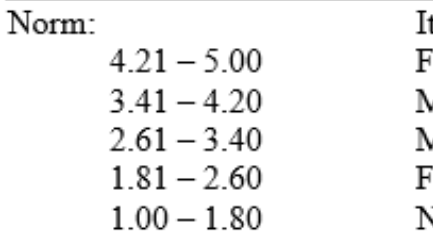 & $\begin{array}{l}\text { Item D } \\
\text { Fully } \\
\text { Much } \\
\text { Moder } \\
\text { Fairly } \\
\text { Not At }\end{array}$ & $\begin{array}{l}\text { Attaine } \\
\text { Attaine } \\
\text { ately A } \\
\text { Attain } \\
\text { tained }\end{array}$ & $\begin{array}{l}\mathrm{d}(\mathrm{Fu} \\
\text { ed (My } \\
\text { dttaine } \\
\text { ed (Fa } \\
\text { (NA) }\end{array}$ & A) & & $\begin{array}{l}\mathrm{Hi} \\
\mathrm{Fa} \\
\mathrm{Lc} \\
\mathrm{V}\end{array}$ & $\begin{array}{l}\text { rerall I } \\
\text { gh } \mathrm{Hig} \\
\text { ir (F) } \\
\text { w (L) } \\
\text { ry Lor }\end{array}$ & $\begin{array}{l}\mathrm{R} \\
(\mathrm{VH})\end{array}$ \\
\hline
\end{tabular}

The results indicate a high status of implementation of the Junior High School Mathematics curriculum with respect to skills and processes. The set of skills and processes set for every Filipino learner is attainable and students are able to demonstrate them. This picture goes with the objectives of implementing a new curriculum. Students today require stronger mathematical knowledge, skills and values to pursue higher education to compete and be part of the technologically oriented welfare and to be informed citizens (Sci-d0st and Mathed, 2011). 
Table 5 displays the mean ratings of the status of implementation of the Junior High School Mathematics Curriculum along values and attitudes.

Table 5

Mean Ratings Showing the Status of the Junior High School Mathematics Curriculum along Values and Attitudes as Assessed by the Administrators, Teachers and Students of Selected Schools in the Division of Ilocos Sur

\begin{tabular}{|c|c|c|c|c|c|c|c|c|}
\hline Values and Attitudes & Adr & $\min$ & Tea & hers & Stud & & As a & thole \\
\hline The learner... & $\overline{\bar{x}}$ & DR & $\overline{\bar{x}}$ & DR & $\overline{\bar{x}}$ & DR & $\overline{\bar{x}}$ & DR \\
\hline $\begin{array}{l}\text { 1. can solve Mathematics problems } \\
\text { with speed and accuracy. }\end{array}$ & 3.95 & A & 3.81 & A & 3.64 & A & 3.80 & A \\
\hline $\begin{array}{l}\text { 2. considers Mathematics that can } \\
\text { develop his ability to think and } \\
\text { reason accurately. }\end{array}$ & 4.10 & A & 4.04 & A & 3.86 & A & 4.00 & A \\
\hline $\begin{array}{l}\text { 3. can always work with a great deal } \\
\text { of certainty that he is following the } \\
\text { correct procedure for solving a } \\
\text { particular problem. }\end{array}$ & 3.80 & A & 3.73 & A & 3.71 & A & 3.75 & A \\
\hline $\begin{array}{l}\text { 4. feels that a logical step-by-step } \\
\text { method is best for solving } \\
\text { problems. }\end{array}$ & 4.25 & $\mathrm{SA}$ & 4.19 & A & 4.09 & A & 4.18 & A \\
\hline $\begin{array}{l}\text { 5. finds different ways to solve } \\
\text { Mathematics problems. }\end{array}$ & 4.25 & $\mathrm{SA}$ & 3.96 & A & 3.98 & A & 4.06 & A \\
\hline $\begin{array}{l}\text { 6. is comfortable expressing his own } \\
\text { ideas on how to look for solutions } \\
\text { to different problems in } \\
\text { Mathematics. }\end{array}$ & 4.25 & $\mathrm{SA}$ & 3.96 & A & 3.72 & A & 3.98 & $\mathrm{~A}$ \\
\hline $\begin{array}{l}\text { 7. uses different techniques to come } \\
\text { up with the correct answer in a } \\
\text { given problem. }\end{array}$ & 4.20 & A & 4.04 & A & 3.78 & A & 4.00 & A \\
\hline $\begin{array}{l}\text { 8. actively look for ways to improve } \\
\text { his mathematical skills. }\end{array}$ & 4.15 & A & 3.96 & A & 3.87 & A & 3.99 & A \\
\hline $\begin{array}{l}\text { 9. believes that Mathematics help } \\
\text { develop his personal values such as } \\
\text { honesty, discipline and foresight } \\
\text { diligence. }\end{array}$ & 4.20 & A & 4.00 & A & 3.80 & A & 4.00 & A \\
\hline $\begin{array}{l}\text { 10. considers Mathematics as a means } \\
\text { of empowerment and } \\
\text { understanding that everyone is } \\
\text { entitled to. }\end{array}$ & 3.90 & A & 3.96 & A & 3.75 & A & 3.87 & A \\
\hline $\begin{array}{l}\text { 11. regards Mathematics that can } \\
\text { provide equal opportunities for } \\
\text { every learner. }\end{array}$ & 4.15 & A & 4.15 & A & 3.77 & A & 4.02 & A \\
\hline $\begin{array}{l}\text { 12. believes that Mathematics is best } \\
\text { learned when every student is } \\
\text { encouraged to participate actively. }\end{array}$ & 4.45 & $\mathrm{SA}$ & 4.27 & $\mathrm{SA}$ & 4.01 & A & 4.24 & A \\
\hline \begin{tabular}{|l|} 
13. is able to solve difficult \\
Mathematics problems.
\end{tabular} & 3.75 & A & 3.81 & A & 3.50 & A & 3.69 & A \\
\hline $\begin{array}{l}\text { 14. is confident he can solve various } \\
\text { problems in my Mathematics class. }\end{array}$ & 3.90 & A & 3.81 & A & 3.50 & A & 3.73 & A \\
\hline \begin{tabular}{|l|}
$\begin{array}{l}\text { 15. finds Mathematics interesting, } \\
\text { stimulating and challenging. }\end{array}$ \\
\end{tabular} & 4.20 & A & 4.04 & A & 3.91 & A & 4.05 & A \\
\hline $\begin{array}{l}\text { 16. concentrates harder on whatever } \\
\text { interests him than most people. }\end{array}$ & 4.20 & A & 3.92 & A & 3.73 & A & 3.95 & A \\
\hline $\begin{array}{l}\text { 17. considers Mathematics as a sensible } \\
\text { and worthwhile endeavor. }\end{array}$ & 4.25 & $\mathrm{SA}$ & 4.00 & A & 3.65 & A & 3.97 & A \\
\hline $\begin{array}{l}\text { 18. strongly believes that Mathematics } \\
\text { is needed in his daily life activities. }\end{array}$ & 4.50 & $\mathrm{SA}$ & 4.58 & $\mathrm{SA}$ & 3.92 & A & 4.33 & $\mathrm{SA}$ \\
\hline $\begin{array}{l}\text { 19. actively works with other students } \\
\text { to develop the spirit of camaraderie. }\end{array}$ & 4.45 & $\mathrm{SA}$ & 4.42 & $\mathrm{SA}$ & 3.78 & A & 4.22 & SA \\
\hline
\end{tabular}




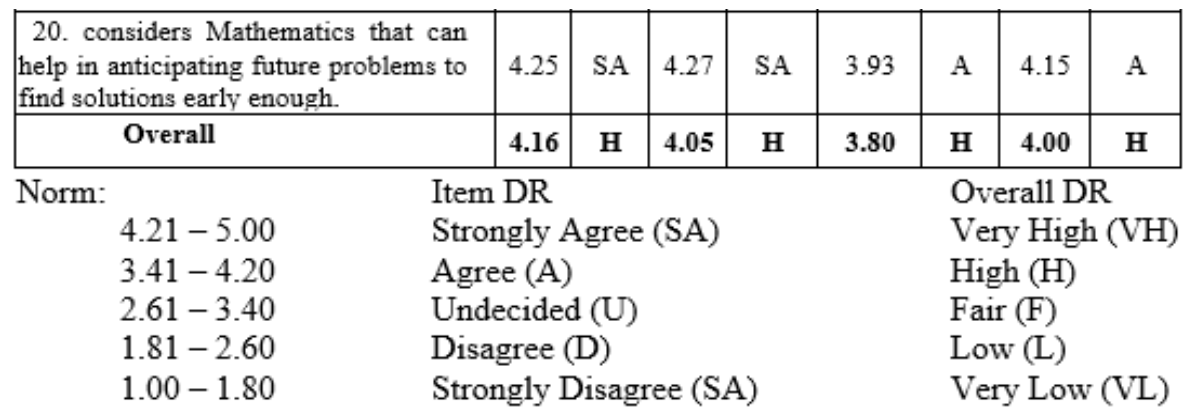

A clear inspection of the table reveals that the respondents as a whole rated values and attitudes as "High." This result is in consonance with Science Education Institute and Philippine Council of Mathematics Teacher Education, Inc. (2011) which says that students have to maintain wholesome attitudes and positive beliefs about Mathematics. Students should develop the attitude that engagement in Mathematics is essential and that perseverance, persistence, reflection, self-assessment and self-confidence are frequently keys to success. Students can learn from each other; cooperative work develops a spirit of camaraderie, teamwork and common purpose. Working with other students exposes students to multiple ways of solving and working with Mathematics.

In a study conducted by Agoot (2006) and Gagto (2001) as cited by Arcaparlas (2016), it was revealed that there is a positive correlation between mathematical attitude and achievement of the respondents. The more positive a student reaction towards Mathematics, the higher would be their academic achievement. Therefore, the students should be provided meaningful activities that would help them develop positive attitude towards the subject.

The three groups of respondents assessed also the Mathematical tools being used by the teachers in teaching Mathematics in the Junior High School. The results are manifested in Table 6.

Table 6

Mean Ratings Showing the Status of the Junior High School Mathematics Curriculum along Mathematical Tools as Assessed by the Administrators, Teachers and Students of Selected Schools in the Division of Ilocos Sur

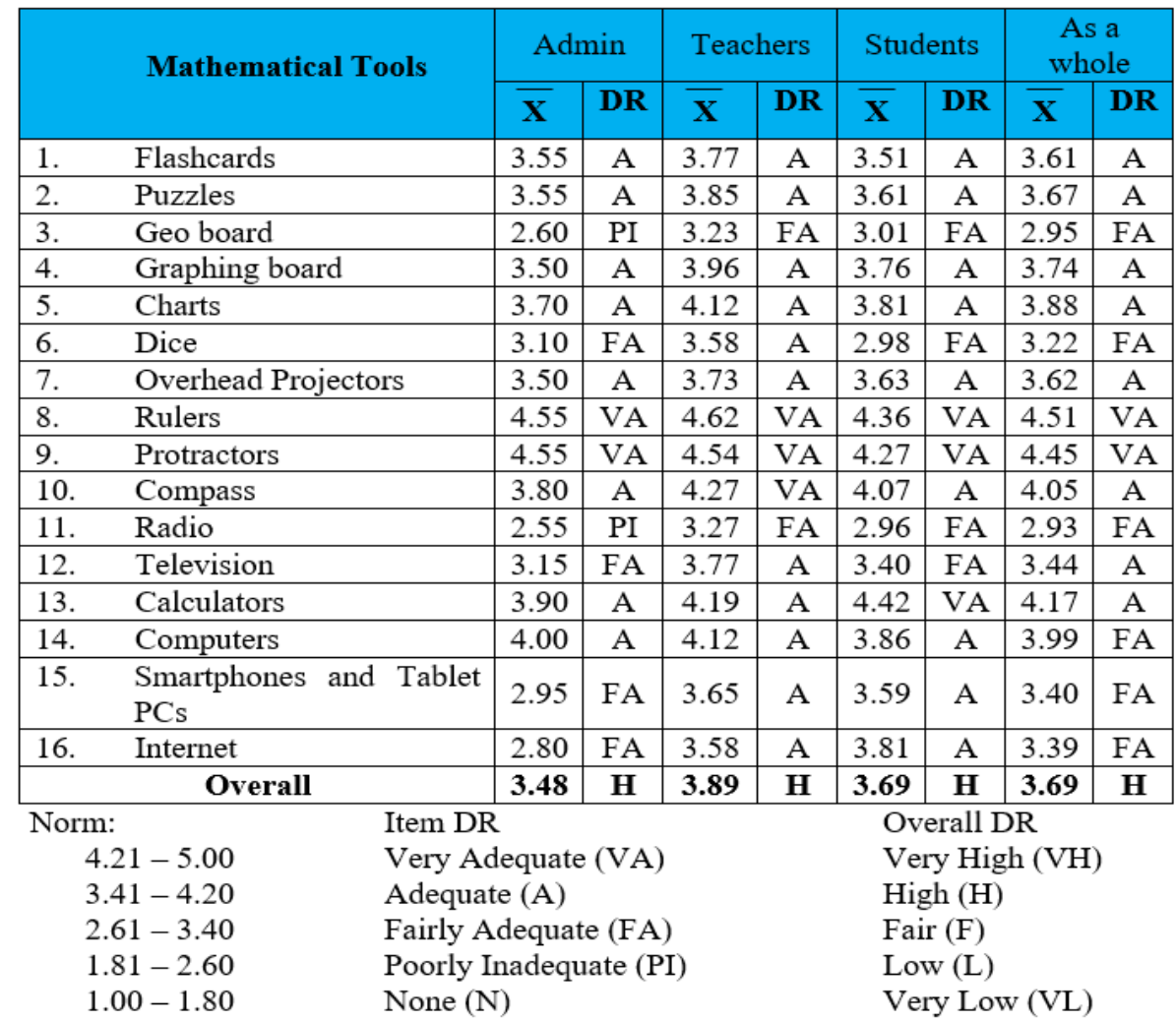


It can be observed that in spite of the "High" overall rating, there were items rated "Fairly Adequate and "Poorly Inadequate." However, this could not be a reason for teaching Mathematics ineffectively. As mentioned by Avila (2016) , mathematical tasks should be viewed as "opportunities to explore Mathematics and come up with reasonable methods for solution." She further stressed that the opportunities for student learning are not created simply by putting students in groups, by placing manipulatives in front of them, or by handling them a calculator. Instead, it is the level and kind of thinking where students engage that determines what they will learn.

Additionally, mathematical tools allow students to be actively engaged in learning Mathematics and deepen their mathematical understanding. These tools include manipulatives and hands-on materials that can be effective for developing, clarifying and applying mathematical concepts. These materials should be carefully integrated into the instructional process. Well-crafted indigenous and alternative materials, thoroughly researched and tested, could, likewise, be effectively used to aid students in learning Mathematics (2011).

This is supported by the study of Katigbak (2011) as mentioned by Lacorte (2014), where he cited that instructional materials facilitate, accelerate and make learning experiences more concrete, meaningful and enjoyable.

However, Lacorte (2014) citing the work of Valencia (2007), concluded in her study that the students of Canossa Schools in Region IV A revealed a satisfactory performance in Mathematics based on the mean results of placement, pre and post-tests. There was an improvement from the pre-test to post test. She accounted this finding to the teachers' skills and competencies in the use of various teaching strategies and instructional materials. She concluded further that there is a highly significant association between academic performance and the teacher's use of various teaching strategies and instructional materials.

Table 7 reveals that the use of cooperative learning is "High". The mean rating implies a collaborative teaching method employed by the teacher where they give guides and clues so students can perform a given task. It may also suggest that they encourage students to be involved in a task which requires cooperation and demonstrating solutions.

Table 7

Item Mean Ratings Showing the Extent of Use of Cooperative Learning in Teaching Junior High School Mathematics in Selected Schools in the Division of Ilocos Sur

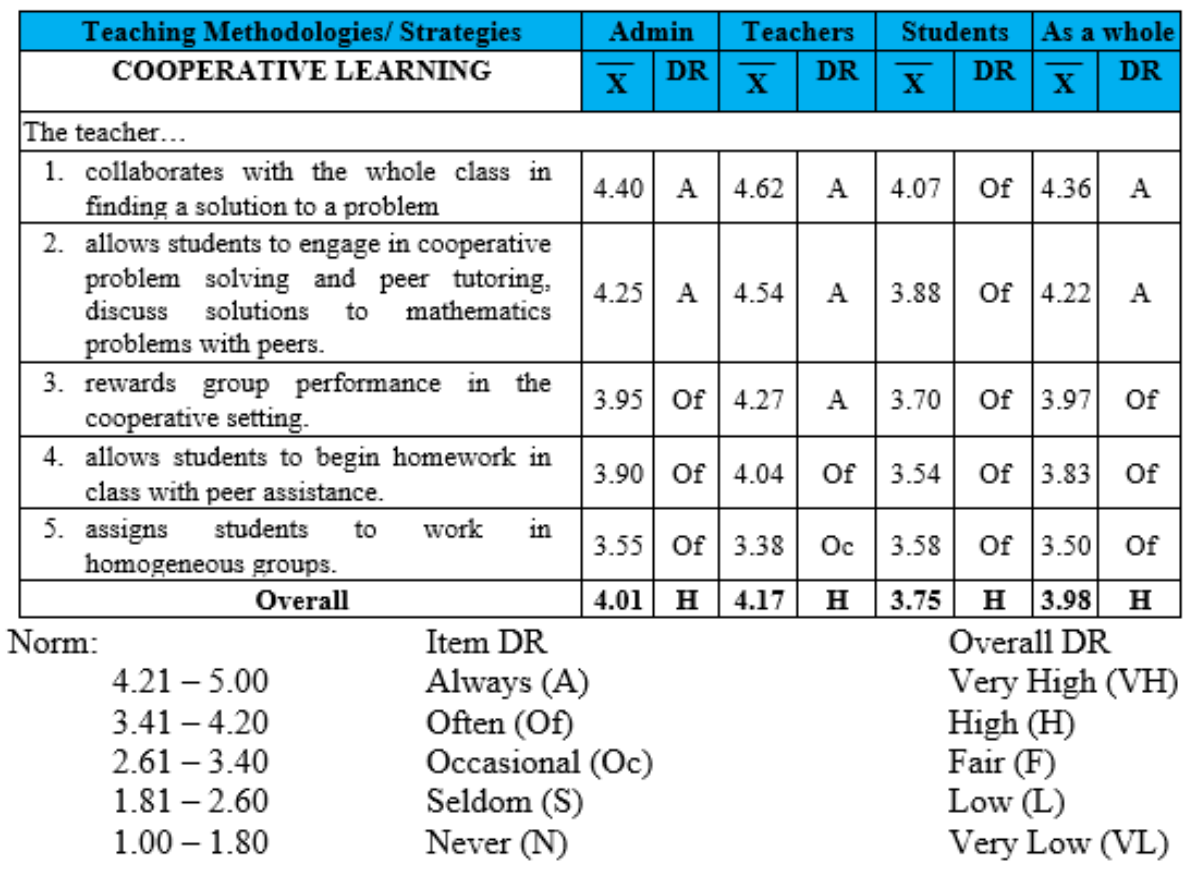

The results also mean that there are instances that some problem solving is done by allowing heterogeneous group of students and do the peer tutoring. This is an implication that teachers tend to utilize cooperative learning in teaching at a high level. 
This is supported by the study of Avila (2016) showing that the teacher-respondents had a high overall level along utilization of cooperative learning strategy in teaching Mathematics. Furthermore, Kusumah and Marsigit (2015) stated that through cooperative learning, the students' response to teachers' information and instruction will empower students in strengthening their reasoning.

Palacpac (2008) recommended in his study that cooperative learning should be applied in teaching other areas of Mathematics such as Arithmetic, Geometry, Trigonometry or even Calculus since he found out its effectiveness in teaching Mathematics II.

Table 8 presents the mean ratings of the respondents on the teacher's use of constructivism in teaching Mathematics.

Table 8

Item Mean Ratings Showing the Extent of Use of Constructivism in Teaching Junior High School Mathematics in Selected Schools in the Division of Ilocos Sur

\begin{tabular}{|c|c|c|c|c|c|c|c|c|c|}
\hline \multirow{2}{*}{\multicolumn{2}{|c|}{$\frac{\text { Teaching Methodologies/ Strategies }}{\text { CONSTRUCTIVISM }}$}} & \multicolumn{2}{|c|}{ Admin } & \multicolumn{2}{|c|}{ Teachers } & \multicolumn{2}{|c|}{ Students } & \multicolumn{2}{|c|}{ As a whole } \\
\hline & & $\overline{\bar{x}}$ & DR & $\overline{\bar{x}}$ & DR & $\overline{\bar{x}}$ & DR & $\overline{\bar{x}}$ & DR \\
\hline \multicolumn{10}{|l|}{ The teacher... } \\
\hline $\begin{array}{l}\text { 1. facilitates learning by } \\
\text { for a stimulating dialo } \\
\text { could evolve and be con }\end{array}$ & $\begin{array}{l}\text { pportunities } \\
\text { at meanings }\end{array}$ & 4.00 & of & 4.15 & Of & 3.62 & Of & 3.93 & Of \\
\hline $\begin{array}{l}\text { 2. guides students throu } \\
\text { and appropriate cognitio }\end{array}$ & $\begin{array}{l}\text { questioning } \\
\text { g. }\end{array}$ & 4.15 & Of & 4.46 & A & 3.81 & of & 4.14 & of \\
\hline $\begin{array}{l}\text { 3. encourages students to } \\
\text { undertaking a learning a }\end{array}$ & pendently in & 4.35 & A & 4.46 & A & 3.85 & Of & 4.22 & A \\
\hline $\begin{array}{l}\text { 4. allows group discussic } \\
\text { of students own ideas. }\end{array}$ & expressions & 4.25 & $\mathrm{~A}$ & 4.31 & A & 4.09 & Of & 4.22 & A \\
\hline 5. allows time for studen & on activity. & 4.20 & Of & 4.23 & $\mathrm{~A}$ & 3.95 & Of & 4.13 & Of \\
\hline \multicolumn{2}{|c|}{ Overall } & 4.19 & $\mathbf{H}$ & 4.32 & VH & 3.86 & $\mathbf{H}$ & 4.13 & $\mathbf{H}$ \\
\hline Norm: & \multicolumn{5}{|l|}{ Item DR } & \multicolumn{4}{|c|}{ Overall DR } \\
\hline $4.21-5.00$ & \multicolumn{5}{|c|}{ Always (A) } & & \multicolumn{3}{|c|}{ Very High (VH) } \\
\hline $3.41-4.20$ & \multicolumn{5}{|l|}{ Often (Of) } & & \multicolumn{3}{|c|}{$\operatorname{High}(\mathrm{H})$} \\
\hline $2.61-3.40$ & \multicolumn{5}{|c|}{ Occasional (Oc) } & & \multicolumn{3}{|c|}{ Fair (F) } \\
\hline $1.81-2.60$ & \multicolumn{5}{|c|}{ Seldom (S) } & & \multicolumn{3}{|c|}{ Low (L) } \\
\hline $1.00-1.80$ & \multicolumn{5}{|c|}{$\operatorname{Never}(\mathrm{N})$} & & \multicolumn{3}{|c|}{ Very Low (VL) } \\
\hline
\end{tabular}

Overall, as shown in the table, the level of utilization on constructivism by the teachers is "High" which means that the teachers continue making students reflect and evaluate accumulated knowledge with an end in view of constructing meaning. Majority of the items got the descriptive rating of "Often" which means that the teachers encourage the learners to work independently in undertaking a learning activity, allow group discussions and free expressions of students' own ideas, and believe in the importance of connecting every lesson to students' interests and experiences and to real-life situations for a more meaningful learning.

The next table presents the mean rating of the respondents in the utilization of the teachers of Reflective Learning in teaching Mathematics. 
Table 9

Item Mean Ratings Showing the Extent of Use of Reflective Learning in Teaching Junior High School Mathematics in Selected Schools in the Division of Ilocos Sur

\begin{tabular}{|c|c|c|c|c|c|c|c|c|}
\hline \multirow{2}{*}{$\begin{array}{c}\text { Teaching Methodologies/ Strategies } \\
\text { REFLECTIVE LEARNING }\end{array}$} & \multicolumn{2}{|c|}{ Admin } & \multicolumn{2}{|c|}{ Teachers } & \multicolumn{2}{|c|}{ Students } & \multicolumn{2}{|c|}{ As a whole } \\
\hline & $\bar{x}$ & DR & $\overline{\mathbf{x}}$ & DR & $\bar{x}$ & DR & $\bar{x}$ & DR \\
\hline \multicolumn{9}{|l|}{ The teacher... } \\
\hline $\begin{array}{l}\text { 1. shares his experiences with the } \\
\text { understanding that, it can help benefit } \\
\text { others who may be able to learn from his } \\
\text { experiences. }\end{array}$ & 4.05 & Of & 4.35 & A & 3.84 & Of & 4.08 & Of \\
\hline $\begin{array}{l}\text { 2. takes action upon his focused thought } \\
\text { about professional practice. He does not } \\
\text { continue in a course of action that he has } \\
\text { realized is not working. }\end{array}$ & 4.05 & of & 4.15 & Of & 3.72 & Of & 3.98 & Of \\
\hline $\begin{array}{l}\text { 3. analyzes his own lessons to see what } \\
\text { worked and what did not. He makes } \\
\text { changes as necessary. When a lesson does } \\
\text { not go well, he learns from it and does not } \\
\text { teach the lesson the same way again. }\end{array}$ & 4.10 & Of & 4.54 & A & 3.88 & Of & 4.17 & Of \\
\hline $\begin{array}{l}\text { 4. knows both his strength and his students' } \\
\text { strengths. His lessons are designed around } \\
\text { their strength and areas of interest to } \\
\text { maximize learning. }\end{array}$ & 4.30 & A & 4.58 & A & 3.76 & Of & 4.21 & A \\
\hline $\begin{array}{l}\text { 5. seeks feedback from many sources, such } \\
\text { as other teachers, students, parents, and } \\
\text { administrators. He is open to constructive } \\
\text { criticism. }\end{array}$ & 4.30 & A & 4.46 & A & 3.73 & Of & 4.16 & Of \\
\hline Overall & 4.16 & $\mathbf{H}$ & 4.42 & VH & 3.79 & & & $\mathbf{H}$ \\
\hline $\begin{array}{l}\text { Norm: } \\
\begin{aligned} & \\
& \\
& \\
& \\
& .41-51-4.20 \\
& 2.61-3.40 \\
& 1.81-2.60 \\
& 1.00-1.80\end{aligned}\end{array}$ & (Oc) & & & & & $\begin{array}{l}\text { Over } \\
\text { Very } \\
\text { High } \\
\text { Fair } \\
\text { Low } \\
\text { Very }\end{array}$ & $\begin{array}{l}\text { all DR } \\
\text { High } \\
\text { (H) } \\
\text { F) } \\
\text { (L) } \\
\text { Low }\end{array}$ & (VH) \\
\hline
\end{tabular}

As manifested in Table 9, the three groups of respondents assessed the five items as "High". This supports the findings of Boud and Walker (1998) as cited by Avila (2016) that reflective teachers are critical of their own practices. For making teaching and learning more meaningful, reflective teachers prefer using different teaching strategies and methods in the classroom. This means that the teacher knows both his own and his students' strengths. Thus, his lessons are designed around their strength and areas of interest to maximize learning as manifested by its overall rating.

Table 10 presents the result of the assessment of the respondents on the teacher's utilization of the experiential and situated learning methodology in teaching the Junior High School Mathematics. 
Table 10

Item Mean Ratings Showing the Extent of Use of Experiential and Situated Learning in Teaching Junior High School Mathematics in Selected Schools in the Division of Ilocos Sur

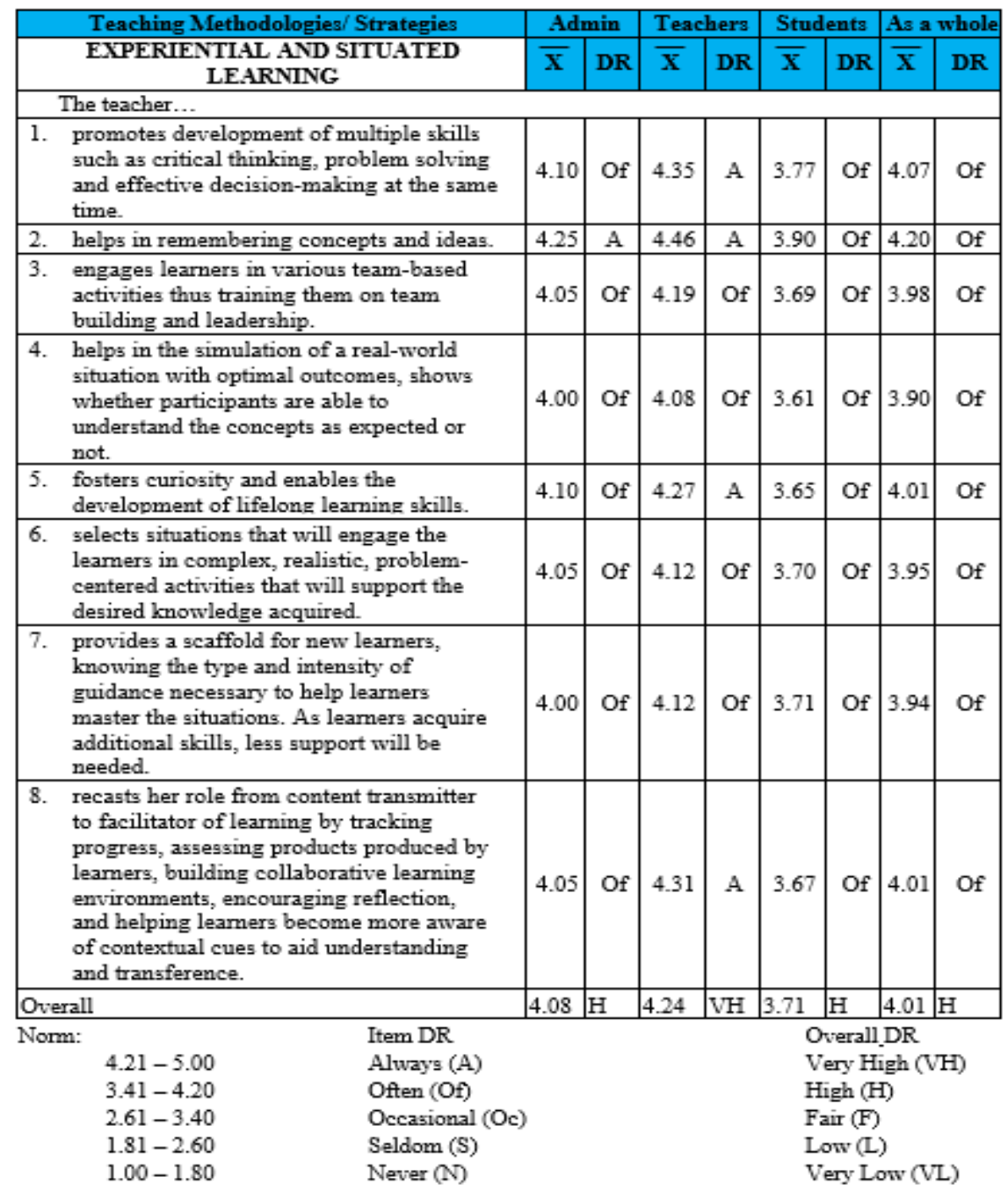

It can be gleaned from the table that the overall rating of the use of experiential and situated learning from the three group of respondents is "High." This reflects that the teacher helps in remembering concepts and ideas and promotes development of multiple skills such as critical thinking, problem solving and effective decision-making at the same time. This is in consonance with the research of Brown et al. (1989) as cited by Difrancesco (2011), that students who were exposed to situated learning method have more insights into their knowledge and to the world that it applies versus students who were exposed to traditional method. The implication of this allows for the understanding of the students as more than just receivers of knowledge.

Table 11 is about the mean ratings of the teacher's extent of use of discovery and inquiry-based learning in teaching Mathematics.

The result signifies that the teacher uses activities that focus the learners' attention on the key ideas or techniques that are being examined and supports an active engagement of the learner in the learning process while the learners stay focus. It also implies that the teacher allows learners to experiment and discover something for themselves and fortifies the importance of asking good questions. 
Table 11

Item Mean Ratings Showing the Extent of Use of Discovery and Inquiry-Based Learning in Teaching Junior High School Mathematics in Selected Schools in the Division of Ilocos Sur

\begin{tabular}{|c|c|c|c|c|c|c|c|c|}
\hline \multirow{2}{*}{$\begin{array}{l}\text { Teaching Methodologies/ Strategies } \\
\text { ISCOVERY AND INQUIRY -BASED } \\
\text { LEARNING }\end{array}$} & \multicolumn{2}{|c|}{ Admin } & \multicolumn{2}{|c|}{ Teachers } & \multicolumn{2}{|c|}{ Students } & \multicolumn{2}{|c|}{ As a whole } \\
\hline & $\mathbf{x}$ & DR & $\mathbf{x}$ & DR & $\mathbf{x}$ & DR & $\mathbf{x}$ & DR \\
\hline \multicolumn{9}{|l|}{ The teacher... } \\
\hline $\begin{array}{l}\text { 1. supports an active engagement of the } \\
\text { learner in the learning process while the } \\
\text { learners are paying more attention. }\end{array}$ & 4.35 & A & 4.58 & A & 3.77 & of & 4.23 & A \\
\hline $\begin{array}{l}\text { 2. allows the learners the opportunity to } \\
\text { experiment and discover something for } \\
\text { themselves. }\end{array}$ & 4.25 & A & 4.58 & A & 3.75 & Of & 4.19 & Of \\
\hline $\begin{array}{l}\text { 3. uses activities that focus their attention on } \\
\text { the key ideas or techniques that are being } \\
\text { examined. }\end{array}$ & 4.30 & A & 4.58 & A & 3.80 & Of & 4.22 & A \\
\hline $\begin{array}{l}\text { 4. creates active involvement that forces the } \\
\text { learners to construct a response and this } \\
\text { results in processing of information } \\
\text { deeper than mere memorization. }\end{array}$ & 4.15 & Of & 4.27 & A & 3.69 & Of & 4.03 & Of \\
\hline $\begin{array}{l}\text { 5. motivates and incorporates the learners } \\
\text { pleasure of successfully solving problems } \\
\text { and recalling information. }\end{array}$ & 4.25 & A & 4.46 & A & 3.71 & Of & 4.14 & Of \\
\hline 6. nurtures student passions and talents. & 4.25 & A & 4.42 & A & 3.74 & Of & 4.14 & Of \\
\hline $\begin{array}{|lll|}\text { 7. empowers student voice and honor } \\
\text { student voice. }\end{array}$ & 4.10 & Of & 4.46 & A & 3.80 & Of & 4.12 & Of \\
\hline $\begin{array}{l}\text { 8. enables students to take ownership of their } \\
\text { learning and to reach their goal. }\end{array}$ & 4.05 & Of & 4.50 & A & 3.80 & Of & 4.12 & of \\
\hline $\begin{array}{l}\text { 9. deepens understanding to go beyond facts } \\
\text { and content. }\end{array}$ & 4.10 & Of & 4.42 & A & 3.78 & Of & 4.10 & Of \\
\hline $\begin{array}{l}\text { 10. fortifies the importance of asking good } \\
\text { questions. }\end{array}$ & 4.20 & Of & 4.50 & A & 3.86 & Of & 4.19 & Of \\
\hline Overall & 4.20 & $\mathbf{H}$ & 4.48 & VH & 3.77 & $\mathbf{H}$ & 4.15 & $\mathbf{H}$ \\
\hline \multicolumn{5}{|l|}{$\begin{aligned} \text { Norm: } & \text { Item DR } \\
4.21-5.00 & \text { Always (A) } \\
3.41-4.20 & \text { Often (Of) } \\
2.61-3.40 & \text { Occasional } \\
1.81-2.60 & \text { Seldom (S) } \\
1.00-1.80 & \text { Never (N) }\end{aligned}$} & \multicolumn{4}{|c|}{$\begin{array}{l}\text { Overall DR } \\
\text { Very High (VH) } \\
\text { High (H) } \\
\text { Fair (F) } \\
\text { Low (L) } \\
\text { Very Low (VL) }\end{array}$} \\
\hline
\end{tabular}

In support to this finding, Dinglasan (2007) as mentioned by Lacorte (2014) found out the effectiveness of a variety of methodologies in teaching Mathematics in two Science High Schools in the Division of Lipa City. These methods include the inductive, deductive, discussion, discovery and integrated. Corollary to these findings was the very satisfactory performance of the students as reflected in their quizzes, recitation, assignment, periodical test and projects. Hence, a highly significant relationship was revealed between the effectiveness of teaching methodologies and the students' academic performance reflected in their grades.

The same study concluded that the use of teaching methods is complemented by that of instructional materials, but also dependent on the nature of the learners, the teacher's personal and professional qualities and the classroom climate.

Overall, the results imply that teachers are committed, effective and efficient in imparting knowledge to the students. They are doing their best to use the most appropriate teaching methodologies and strategies in presenting their lesson to achieve maximum learning. On the other hand, the results also suggest that these methods/ strategies are innovative, studentcentered, and interactive. This would also mean a strict compliance to the teaching methodologies and strategies suggested in the DepEd K-12 curriculum (2013) to ensure a better student performance.

Table 12 presents the levels of critical thinking and problem-solving skills of the students in the 20 respondent schools.

As depicted from the table, it is observable that the schools' levels of performance along these skills are almost the same. Only few of them obtained an average equivalent to very satisfactory. This implies that the student-respondents of the selected schools in the Division of Ilocos Sur have an average mastery of the concepts of the learning areas during the School Year 2017-2018. The findings suggest that the levels of the students' critical thinking and problem-solving skills can still be improved. 
Table 12

Grade 9 Students' Levels of Critical Thinking and Problem-Solving Skills

\begin{tabular}{|c|c|c|c|c|c|c|}
\hline \multirow[t]{2}{*}{ Schools } & \multicolumn{2}{|c|}{$\begin{array}{c}\text { Problem Solving } \\
\text { Skills }\end{array}$} & \multicolumn{2}{|c|}{$\begin{array}{c}\text { Critical } \\
\text { Thinking Skills }\end{array}$} & \multicolumn{2}{|c|}{ Overall } \\
\hline & $\overline{\boldsymbol{X}}$ & DR & $\overline{\boldsymbol{X}}$ & DR & $\overline{\boldsymbol{X}}$ & DR \\
\hline A & 10.35 & $\mathrm{~S}$ & 11.90 & $\mathrm{~S}$ & 22.25 & $\mathrm{~S}$ \\
\hline B & 12.67 & $\mathrm{~S}$ & 12.06 & $\mathrm{~S}$ & 24.72 & $\mathrm{~S}$ \\
\hline $\mathrm{C}$ & 12.00 & $\mathrm{~S}$ & 10.50 & $\mathrm{~S}$ & 22.50 & $\mathrm{~S}$ \\
\hline D & 11.38 & $\mathrm{~S}$ & 10.74 & $\mathrm{~S}$ & 22.12 & $\mathrm{~S}$ \\
\hline$E$ & 11.90 & $\mathrm{~S}$ & 11.50 & $\mathrm{~S}$ & 23.40 & $\mathrm{~S}$ \\
\hline $\mathrm{F}$ & 12.65 & $\mathrm{~S}$ & 11.38 & $\mathrm{~S}$ & 24.03 & $\mathrm{~S}$ \\
\hline $\mathrm{G}$ & 14.17 & $\mathrm{~S}$ & 10.83 & $\mathrm{~S}$ & 25.00 & $\mathrm{~S}$ \\
\hline $\mathrm{H}$ & 12.25 & $\mathrm{~S}$ & 12.06 & $\mathrm{~S}$ & 24.31 & $\mathrm{~S}$ \\
\hline I & 12.43 & $\mathrm{~S}$ & 12.94 & $\mathrm{~S}$ & 25.38 & $\mathrm{~S}$ \\
\hline $\mathbf{J}$ & 12.75 & $\mathrm{~S}$ & 14.00 & $\mathrm{~S}$ & 26.75 & $\mathrm{~S}$ \\
\hline $\mathrm{K}$ & 13.00 & $\mathrm{~S}$ & 12.50 & $\mathrm{~S}$ & 25.50 & $\mathrm{~S}$ \\
\hline $\mathrm{L}$ & 13.00 & $\mathrm{~S}$ & 13.00 & $\mathrm{~S}$ & 26.00 & $\mathrm{~S}$ \\
\hline $\mathrm{M}$ & 12.20 & $\mathrm{~S}$ & 13.30 & $\mathrm{~S}$ & 25.50 & $\mathrm{~S}$ \\
\hline $\mathrm{N}$ & 12.21 & $\mathrm{~S}$ & 12.21 & $\mathrm{~S}$ & 24.43 & $\mathrm{~S}$ \\
\hline $\mathrm{O}$ & 16.11 & VS & 15.59 & VS & 31.70 & VS \\
\hline $\mathrm{P}$ & 12.50 & $\mathrm{~S}$ & 13.33 & $\mathrm{~S}$ & 25.83 & $\mathrm{~S}$ \\
\hline $\mathrm{Q}$ & 12.33 & $\mathrm{~S}$ & 13.00 & $\mathrm{~S}$ & 25.33 & $\mathrm{~S}$ \\
\hline $\mathrm{R}$ & 16.00 & VS & 12.75 & $\mathrm{~S}$ & 28.75 & $\mathrm{~S}$ \\
\hline $\mathrm{S}$ & 13.10 & $\mathrm{~S}$ & 13.10 & $\mathrm{~S}$ & 26.20 & $\mathrm{~S}$ \\
\hline $\mathrm{T}$ & 14.52 & $\mathrm{~S}$ & 13.59 & $\mathrm{~S}$ & 28.11 & $\mathrm{~S}$ \\
\hline As a whole & 13.04 & $\mathbf{S}$ & $\mathbf{1 2 . 8 3}$ & $\mathbf{S}$ & 25.87 & $\mathbf{S}$ \\
\hline \multicolumn{4}{|c|}{ Descriptive Rating 25 Item DR } & \multicolumn{3}{|c|}{ Overall } \\
\hline \multicolumn{2}{|c|}{ Outstanding $(\mathrm{O})$} & \multicolumn{2}{|c|}{$20.01-25.00$} & \multicolumn{3}{|c|}{$40.01-50.00$} \\
\hline \multicolumn{2}{|c|}{ Very Satisfactory (VS) } & \multicolumn{2}{|c|}{$15.01-20.00$} & \multicolumn{3}{|c|}{$30.01-40.00$} \\
\hline \multicolumn{2}{|c|}{ Satisfactory (S) } & \multicolumn{2}{|c|}{$10.01-15.00$} & \multicolumn{3}{|c|}{$20.01-30.00$} \\
\hline \multicolumn{2}{|l|}{ Fair (F) } & \multicolumn{2}{|c|}{$5.01-10.00$} & \multicolumn{3}{|c|}{$10.01-20.00$} \\
\hline \multicolumn{2}{|l|}{ Poor (P) } & \multicolumn{2}{|c|}{$0.00-5.00$} & \multicolumn{3}{|c|}{$0.01-10.00$} \\
\hline
\end{tabular}

The same conclusion was revealed in the study of Ubarre (2016) in which she found out that the overall level of Mathematics performance of the fourth-year students from selected secondary schools in the division of Ilocos Sur is "Satisfactory." However, Alcantara and Basca (2017) disclosed that the level of critical thinking of the Grade 7 respondents from the different schools of Batangas is above average. Moreover, the level of problem solving of the same set of respondents is also above average. The researchers concluded students were able to interpret data, answers questions and statements, able to examine ideas and detecting argument working and arriving at the answers on their own thinking and able to evaluate questions to arrive answers. They can also manifest understanding verbal description of a problem situation and able to give numerical answer to a stated question by making use of mathematical relationships between quantities.

Table 13 shows the correlation analysis between the status of the Junior High School Mathematics Curriculum and the teacher's teaching methodologies and strategies.

Table 13

Correlation Analysis of the Status of the Junior High School Mathematics Curriculum and Teacher's Teaching-Learning Methodologies and Strategies

\begin{tabular}{|c|c|c|c|c|c|c|}
\hline \multirow[b]{2}{*}{$\begin{array}{l}\text { Status of the Junior } \\
\text { High School } \\
\text { Mathematics } \\
\text { Curriculum }\end{array}$} & \multicolumn{6}{|c|}{ Teaching-Learning Methodologies and Strategies } \\
\hline & $\begin{array}{l}\text { Cooperative } \\
\text { Learning }\end{array}$ & $\begin{array}{c}\text { Construct } \\
\text { ivism }\end{array}$ & $\begin{array}{c}\text { Reflective } \\
\text { Learning }\end{array}$ & $\begin{array}{c}\text { Experiential } \\
\text { and Situated } \\
\text { Learning }\end{array}$ & $\begin{array}{c}\text { Discovery } \\
\text { and Inquiry- } \\
\text { Based } \\
\text { learning }\end{array}$ & $\begin{array}{l}\text { Method } \\
\text { Overall }\end{array}$ \\
\hline Content & $.582 * *$ & $.601 * *$ & $.594 * *$ & $.649 * *$ & $.631 * *$ & $.661 * *$ \\
\hline Contexts & $.681 * *$ & $.733 * *$ & $.704 * *$ & $.770 * *$ & $.766^{* * *}$ & $.790 * *$ \\
\hline Skills and Processes & $.659 * *$ & $.679 * *$ & $.646 * *$ & $.721 * *$ & $.693 * *$ & $.734 * *$ \\
\hline Values and Attitudes & $.646 * *$ & $.717^{* * *}$ & $.676^{* *}$ & $.753^{* * *}$ & $.748^{* * *}$ & $.766 * *$ \\
\hline Mathematical Tools & $.523 * *$ & $.504 * *$ & $.370 * *$ & $.482^{* * *}$ & $.464 * *$ & $.503 * *$ \\
\hline Status Overall & $.733 * *$ & $.767 * *$ & $.710 * *$ & $.800 * *$ & $.783 * *$ & $.819 * *$ \\
\hline
\end{tabular}


Table 13 reveals a significant relationship of the combined components indicating the status of implementation of the Junior High School Mathematics Curriculum and the teaching learning methodologies and strategies. The values in the table reflect a strong, direct, and positive relationship between the two groups of variables. The same picture is seen along the individual teaching methodologies where each posted a significant relationship with the status of implementation of the Junior High School Mathematics Curriculum.

Cooperative Learning as a teaching methodology is directly related to the content, contexts, skills and processes, values and attitudes, and mathematical tools. The status of implementation of the Mathematics curriculum is also correlated to the teaching methodology. Cooperative learning, when used in the teaching-learning process, produces a positive outcome in terms of content, contexts, skills and processes, values and attitudes and the use of mathematical tools. The effective and efficient use of cooperative learning can result in a better status of implementation of the Junior High School Mathematics curriculum. This is supported by the conclusions made by Palacpac (2008) that, (1) Cooperative learning improves and accelerates the Mathematics skills and abilities of the students especially when dealing with Algebra; (2) Students who work and cooperate together as a team achieve better results in comprehension and problem-solving skills; (3) Cooperative learning method of instruction will result on the similarity of the students' scores because sense of cooperation and teamwork are prevalent.

Constructivism is also found to be correlated to the status of implementation of the Junior High School Mathematics curriculum. The values indicate that when constructivist approach is applied in a classroom setting, it will definitely yield a favorable outcome. Wherein, the learners see the connection of every lesson to their own experiences and real-life situations, thus, maximum learning is achieved. This is similar to the conclusion of Kim (2005) in his study that students who are taught using a constructivist teaching approach responded more positively to constructivist teaching than the students who were taught through traditional teaching methods.

A correlation is also seen between reflective learning and the overall status of implementation of the Junior High School Mathematics curriculum. It signifies a positive and direct relationship between the two variables. All of the components of the curriculum posted positive and significant relationships with reflective learning. The same conclusion can be deduced that whenever reflective learning is highly implemented in the teaching-learning process, a high-level status of implementation of the Junior High School Mathematics curriculum can be expected. This is supported by Makofsky (2016) in her article that reflective learners avoid rote memorization and repetition. Instead, they review new information, form questions and consider real-life applications, thus presenting well-rounded, philosophical understanding of the subject.

Another methodology is Experiential and Situated Learning, which according to Wolfe and Byrne (1975) as mentioned by Buena (2013), it is participative, interactive, and applied. It allows contact with the environment, and exposure to processes that are highly variable and uncertain. It involves the whole-person; learning takes place on the affective and behavioral dimensions as well as on the cognitive dimension. This method in Math instruction allows students to actually experience math. This methodology revealed a significant relationship to the components of the Mathematics curriculum. This may mean that students' mathematical skills could be cultivated and nourished by letting them do the math. As John Dewey have said as cited by Buena (2013), students learn best through their experiences, what they see, hear and do.

Discovery and Inquiry-based learning is another critical method that is directly related to the Junior High School Mathematics curriculum. Thus, it is concluded based on the result that Discovery and Inquiry-based learning may provide a field for acquiring new knowledge and may lead to observable changes in the learners' behavior towards Mathematics. As mentioned by Carroll and Beman (2015) that discovery learning promotes student exploration and collaboration with teachers and peers to solve problems. They further stressed that learners are also able to direct their own inquiry and be actively involved in the learning process which helps with student motivation. This is further supported by the conclusions of Laursen et al., that students in the study acquired deeper learning, higher gains in in persistence, improved thinking and problem-solving skills, and provided better support for the lower achieving students. 
Furthermore, Lacorte (2014), citing the work of Valenzuela (2011), concluded that variation in the use of both teaching strategies and instructional materials motivates students, maximizes their class participation and improves their academic performance. She also suggested the use of more innovative strategies and technological tools as that of using a computer in the presentation of lessons to strengthen the students' awareness of the wonders of modern technology.

Table 14 presents the regression analysis on the students' critical thinking skills and teaching methodologies and strategies.

Table 14

Regression Analysis of the Students' Critical Thinking on the Teacher's Teaching-Learning Methodologies and Strategies

\begin{tabular}{|c|c|c|c|}
\hline Components & Beta & $\mathrm{T}$ & Sig. $\mathbf{t}$ \\
\hline Cooperative Learning & .081 & .893 & $p>05$ \\
\hline Constructivism & .181 & 1.544 & $\mathrm{p}>05$ \\
\hline Reflective Learning & .093 & .963 & $p>05$ \\
\hline Experiential and Situated Learning & -.175 & -1.227 & $\mathrm{p}>05$ \\
\hline Competencies & -.134 & -1.001 & $\mathrm{p}>05$ \\
\hline $\begin{array}{l}\text { MultR }=.130 \\
\mathrm{RSq}=.017\end{array}$ & & & \\
\hline
\end{tabular}

Table 14 shows the regression analysis on the students' level of critical thinking skills and the teaching-learning methodologies and strategies of teachers in teaching Mathematics.

It is presented in the table that the level of the students' critical thinking skills is not significantly influenced by the five prescribed teaching-learning methodologies and strategies. The results imply that the level of critical thinking skills of students does not depend on the teacher's methodologies and strategies of teaching. This is parallel to the conclusions of Katigbak (2011) as cited by Lacorte (2014) that the use of teaching methods is generally effective in teaching, but its effectiveness depends much on the nature of the learners, the difficulty of the lesson, the availability and adequacy of instructional materials, the teacher's professional qualities and the classroom climate.

Table 15 reveals the regression analysis on the level of problem solving skills of the students and the teacher's teaching methodologies and strategies.

Table 15

Regression Analysis of the Students' Problem-Solving Skills on the Teacher's Teaching-Learning Methodologies and Strategies

\begin{tabular}{|c|c|c|c|}
\hline Components & Beta & $\mathrm{T}$ & Sig. $t$ \\
\hline Cooperative Learning & .141 & 1.252 & $p>05$ \\
\hline Constructivism & .178 & 1.533 & $\mathrm{p}>0.05$ \\
\hline Reflective Learning & -.010 & -.106 & $p>05$ \\
\hline Experiential and Situated Learning & -.172 & -1.226 & $\mathrm{p}>05$ \\
\hline Competencies & .079 & .602 & $\mathrm{p}>0.05$ \\
\hline MultR $=.225$ & & & \\
\hline
\end{tabular}

The results of multiple regression analysis as reflected from the table suggest that the students' level of problem solving skills is not significantly influenced by any of the teaching methodologies and strategies of teachers in teaching the subject. 
This means that the use of these methodologies and strategies has not contributed significantly on the level of problem solving skills of students. The computed regression coefficients did not meet the required probability level. This implies that the methodologies and strategies do not affect the problem-solving skills of the students. This is analogous with the study of Avila (2016) which state that, the teachers' role is to encourage their students explore until coming up with the right answer guided with mathematical rules. The students eventually learn the values of patience and hard work which are crucial in dealing life's situations. Hence, this is a clear manifestation that in math we do not only deal with shapes or figures beyond these are lifetime lessons. But this happens only when students make learning meaningful.

\section{Conclusions}

From the findings of the study, the following conclusions are drawn:

The overall status of implementation of the Junior High School Mathematics Curriculum along content standards, contexts, skills and processes, values and attitudes, and utilization of mathematical tools from the selected secondary schools in the division of Ilocos Sur is "High." The teachers' extent of use of the suggested methodologies and strategies in teaching Mathematics in the Junior High School is also "High." Furthermore, the Grade 9 students' levels of critical thinking and problem-solving skills is "Satisfactory." Moreover, there existed a significant relationship of the indicators of the status of implementation of the Junior High School Mathematics Curriculum and the facts related to the teaching learning methodologies and strategies. Lastly, the levels of students' critical thinking and problem-solving skills are not influenced by the teaching strategies and methodologies being used by the teachers.

\section{Recommendations}

The overall rating of the status of implementation of the Junior High School Mathematics Curriculum was high. However, there are some content areas where the students are found weak. Therefore, more attention and activities should be given to improve and develop their knowledge and skills in Mathematics.

School administrators should be encouraged to establish linkages with stakeholders or initiate income generating activities, tap alumni for their support, and include in the school budget to address the problems on Mathematical tools needed for maximum learning.

Teachers should be encouraged to use different mathematical tools which are relevant and appropriate to the subject content to facilitate teaching and learning. They should be creative to find ways and means to construct or develop mathematical tools in order to help the students easily learn and appreciate the different topics.

To meet the challenges of the 21 st Century learning, administrators and teachers should take their post graduate studies because this will hone their management and teaching skills. Further, they should attend seminars/ workshops/ trainings in order to keep abreast with the new trends, methods, and approaches in teaching Mathematics.

The Department of Education should offer more training programs for secondary Mathematics teachers especially on the different teaching methodologies and strategies as stated from the conceptual framework of Mathematics education. Teachers should enhance their teaching practices and employ appropriate techniques and methods in teaching so that students would easily understand their Mathematics lessons. They should use the best teaching practices suited to the students and provide more challenging and enriching activities to achieve higher mastery level which will lead to the development of knowledge, attitude and skills, particularly the critical thinking and problem-solving skills of the students. School heads and teachers then should work hand in hand on how to utilize these methodologies and strategies to achieve maximum learning.

Mathematics is a subject that develops critical thinking and problem-solving skills. Therefore, students are advised to learn these not only because they are essentials in Mathematics but they are also applicable in real life situations. They should be encouraged to actively join, participate or engage themselves in different Mathematics-related activities like attending or joining contests to further enhance their knowledge and skills in the subject. They should take seriously the mathematics subject even if this is not their field of interest. They should improve their study habits, participate in discussions and problem-solving activities, and make reflections in their learning and applications in their real life. 


\section{Limitations and Future Studies}

This study, however, has some limitations. The results have represented the status of the implementation of the Junior High School Mathematics curriculum in the division of Ilocos Sur. The results should not be presumed therefore to be true to all divisions. As this study aims to improve the critical thinking and problem solving skills of the Grade 9 students, results of which have been disseminated for its consideration. For future studies along this topic, other variables may be considered which may affect/ influence the implementation of the Junior High School Mathematics curriculum.

\section{Acknowledgment}

The researcher expresses her indebtedness to Dr. Francisco D. Lopez(+), former SUC president of Ilocos Sur Polytechnic State College, Dr. Gilbert R. Arce, Dr. Wilma Ponce, Dr. Jocelyn L. Absolor, and Dr. Corazon Q. Quitevis.

\section{References}

Alcantara, E. C. \& Basca, J. M. P. (2017). Critical thinking and problem-solving skills in Mathematics of Grade-7 public secondary students. Asia Pacific Journal of Multidisciplinary Research, 5(4). 21-27. http://www.apjmr.com.

Avila, V. P. (2016). Reflective Professional Development of Mathematics Teachers in Public Secondary Schools, Division of Ilocos Sur [Unpublished Doctoral Dissertation]. University of Northern Philippines.

Arcaparlas, D. A. (2016). Statistics Ability of the Second-year Social Work Students of the University of Northern Philippines [Unpublished Master's Thesis] University of Northern Philippines.

Atlantic Evaluation and Research Consultants, Inc. (2008). Intermediate Program Review. https://www.gov.nl.ca/education/files/publications_k12_intermediate_literature-review-final-final-1.pdf

Ballerta, C. A. (2016). Performance in Geometry of the third-year students of Ilocos Sur National High School. [Unpublished Master's Thesis]. University of Northern Philippines.

Brown, C., Murphy, T.J., Nanny, M. (2003). Turning Techno savvy into info savvy: Integrating Information literacy into the college curriculum. The Journal of Academic Librarianship, 29(6), 386-398. https://doi.org/10.1016/j.jal.2003.08.005

Buena, V. (2013). Experiential and situated learning strategies. https://prezi.com/ngf8x57bm6xm/experiential-and-situatedlearning-strategies/

Caprioara., D. (2015). Problem solving-purpose and means of learning mathematics in school. Procedia - Social and Behavioral Sciences, 191(2015) 1859-1864. https://doi.org/10.1016/j.sbspro.2015.04.332

Carroll, J., \& Beman, V. (2015). Boys, inquiry learning and the power of choice in middle school English classroom. Adolescent Success. Australian Journal of Middle Schooling, 15(1), 4-17. https://acuresearchbank.acu.edu.au/item/85z53/boys-inquiry-learning-and-the-power-of-choice-in-a-middle-school-englishclassroom

Cruz, I. (2010). Pros and cons in the K + 12 basic education debates. http://mlephil.wordpress.com/2010/10/14/pros.consof-the-k12-debate

Difrancesco, P. (2011). The Role of situated Learning in Experiential Education: An Ethnographic Study of the KnowledgeConstruction Process of Pharmacy Students during their Clinical Rotations [Doctoral Dissertation, University of Massachussets] https://scholarworks.umb.edu/doctoral_dissertations/29/

Espejo, R. F. (2011). Mathematics Performance of the First-year Students in Candon National High School, Candon City Division. [Unpublished Master's Thesis] University of Northern Philippines.

Jimenez, M. V. (2012). Achievement in Geometry of the Third-year Students in Candon National High School, Division of Candon City [Unpublished Master's Thesis]. University of Northern Philippines. 
K to 12 Mathematics Curriculum Guide. (2013). https://www.slideshare.net/azenithcastro/mathcurriculumguidegrades 110 december 2013

K to 12 Toolkit. (2012). https://www.seameo-innotech.org/portfolio_page/k-to-12-toolkit/

Kim, J. S. (2005). The effects of a constructivist teaching approach on students' academic achievement, self-concept, and learning strategies. Asia Pacific Review, 6(1), 7-19. https://files.eric.ed.gov/fulltext/EJ728823.pdf

Kusumah \& Marsigit (2015). The philosophy of mathematics education and current trends of mathematics teaching practice. Seameo Regional Centrex for QITEP in Mathematics.

Lacorte, E. A. (2014). Implementation of the K to 12 program in selected private and public schools in Lucban, Quezon. https://www.academia.edu/6791837/Research_K_to_12_chapters_1_to_5_READINESS

Laursen S., M. L. Hassi, M. Kogan, A. B. Hunter, and T Weston. Evaluation of the IBL Mathematics Project: Student and Instructor Outcomes of Inquiry-Based Learning in College Mathematics. https:/www.colorado.edu/eer/sites/default/files/attached-files/iblmathreportall_050211.pdf

Learner's Material for Mathematics Grade 9. (2014). https://www.slideshare.net/lhoralight/math-37132231

Makofsky, N. (2016). Reflective learning style. https://classroom.synonym.com/reflective-learning-style-5373027.html

Morris, P. (2014). The Context of Curriculum Development in Hong Kong. Asian Journal of Public Administration, 7(1), 18-35. https://www.researchgate.net/publication/261616889

Palacpac, K. K. A. (2008). The Effectiveness of Cooperative Learning in Teaching Mathematics II [Unpublished Master's Thesis] University of Northern Philippines.

Science Education Institute \& Philippine Council of Mathematics Teacher Education, Inc. (2011). Mathematics Framework for Philippine Basic Education. https://www.sei.dost.gov.ph/images/downloads/publ/sei_mathbasic.pdf

The Mathematics Kindergarten to Grade 9 Program of Studies (2007).

https://education.alberta.ca/media/3115252/2016_k_to_9_math_pos.pdf

The University of the West Indies. (n. d.). https://sta.uwi.edu

Ubarre. L. T. (2016). Extent of Teaching Practices in Mathematics of Selected Secondary Schools in the Division of Ilocos Sur [Unpublished Doctoral Dissertation] University of Northern Philippines.

1987 Philippine Constitution 